P. Tropper $\cdot$ C. E. Manning $\cdot$ E. J. Essene $\cdot$ L.-S. Kao

\title{
The compositional variation of synthetic sodic amphiboles at high and ultra-high pressures
}

Received: 7 July 1999 / Accepted: 27 December 1999

\begin{abstract}
Sodic amphiboles in high pressure and ultrahigh pressure (UHP) metamorphic rocks are complex solid solutions in the system $\mathrm{Na}_{2} \mathrm{O}-\mathrm{MgO}-\mathrm{Al}_{2} \mathrm{O}_{3}-\mathrm{SiO}_{2}-$ $\mathrm{H}_{2} \mathrm{O}$ (NMASH) whose compositions vary with pressure and temperature. We conducted piston-cylinder experiments at $20-30 \mathrm{kbar}$ and $700-800{ }^{\circ} \mathrm{C}$ to investigate the stability and compositional variations of sodic amphiboles, based on the reaction glaucophane $=2$ jadeite + talc, by using the starting assemblage of natural glaucophane, talc and quartz, with synthetic jadeite. A close approach to equilibrium was achieved by performing compositional reversals, by evaluating compositional changes with time, and by suppressing the formation of Na-phyllosilicates. STEM observations show that the abundance of wide-chain structures in the synthetic amphiboles is low. An important feature of sodic amphibole in the NMASH system is that the assemblage jadeite-talc \pm quartz does not fix its composition at glaucophane. This is because other amphibole species such as cummingtonite $(\mathrm{Cm})$, nyböite (Nyb), Al-Na-cummingtonite (Al-Na-Cm) and sodium anthophyllite (Na-Anth) are also buffered via the model reactions: 3cummingtonite +4 quartz $+4 \mathrm{H}_{2} \mathrm{O}=7$ talc, nyböite +3 quartz $=3$ jadeite + talc, 3Al-Na-cumming-
\end{abstract}

Publication number 516 from the Mineralogical Laboratory of the University of Michigan

P. Tropper $(\bowtie) \cdot$ E. J. Essene $\cdot$ L.-S. Kao

Department of Geological Sciences, University of Michigan,

2534 C.C. Little Building, Ann Arbor, MI 48109-1063, USA

C. E. Manning

Department of Earth and Space Sciences,

University of California at Los Angeles,

595 Charles E. Young Drive East, Geology Building,

Los Angeles, CA 90095-1567, USA

Present address:

P. Tropper

Institut für Mineralogie und Petrographie,

Universität Innsbruck, Innrain 52, 6020 Innsbruck, Austria

e-mail: Peter.Tropper@uibk.ac.at

Editorial responsibility: T. L. Grove tonite +11 quartz $+2 \mathrm{H}_{2} \mathrm{O}=6$ jadeite +5 talc, and 3 sodium anthophyllite +13 quartz $+4 \mathrm{H}_{2} \mathrm{O}=3$ jadeite +7 talc. We observed that at all pressures and temperatures investigated, the compositions of newly grown amphiboles deviate significantly from stoichiometric glaucophane due to varying substitutions of $\mathrm{Al}^{\mathrm{IV}}$ for $\mathrm{Si}$, $\mathrm{Mg}$ on the M(4) site, and Na on the A-site. The deviation can be described chiefly by two compositional vectors: $\left[\mathrm{Na}^{\mathrm{A}} \mathrm{Al}^{\mathrm{IV}}\right]<=>\left[\square^{\mathrm{A}} \mathrm{Si}\right]$ (edenite) toward nyböite, and $\left[\mathrm{Na}^{(\mathrm{M} 4)} \mathrm{Al}{ }^{\mathrm{VI}}\right]<=>\left[\mathrm{Mg}^{(\mathrm{M} 4)} \mathrm{Mg}^{\mathrm{VI}}\right]$ toward cummingtonite. The extent of nyböite and cummingtonite substitution increases with temperature and decreases with pressure in the experiments. Similar compositional variations occur in sodic amphiboles from UHP rocks. The experimentally calibrated compositional changes therefore may prove useful for thermobarometric applications.

\section{Introduction}

High pressure metamorphic belts play an important role in deciphering the evolution of collisional orogens and the Earth's volatile budget (Maruyama et al. 1996). Most of the information is gathered from relict mineral assemblages, which often represent a remnant of an earlier high pressure/low temperature stage and are found as eclogites and blueschists. The latter are commonly regarded as "hydrous" rocks because they contain $\mathrm{H}_{2} \mathrm{O}$-bearing phases like glaucophane, paragonite, clinozoisite, and lawsonite, whereas eclogites are often considered to be "dry" rocks containing anhydrous minerals like garnet, omphacite, quartz, rutile, and kyanite (Carswell 1990). However, hydrous minerals such as phengite, epidote, and amphibole are also found in crustal eclogites, and experimental investigations of the system basalt $-\mathrm{H}_{2} \mathrm{O}$ show that hydrous minerals are stable to $25 \mathrm{kbar}$ at temperatures of $600-800{ }^{\circ} \mathrm{C}$ (Essene et al. 1970; Pawley and Holloway 1993; Liu et al. 1996). These observations suggest that hydrous minerals 
provide an important record of the transport and liberation of fluids in deep environments. One of the most important hydrous minerals in high-pressure rocks is sodic amphibole. The stability of glaucophane at low temperatures and high pressures provides the basis for the definition of the blueschist facies in mafic bulkcompositions. In addition, recent observations of glaucophane $\left[\square \mathrm{Na}_{2} \mathrm{Mg}_{3} \mathrm{Al}_{2} \mathrm{Si}_{8} \mathrm{O}_{22}(\mathrm{OH})_{2}\right]$ and nyböite $\left[\mathrm{NaNa}_{2} \mathrm{Mg}_{3} \mathrm{Al}_{2} \mathrm{Si}_{7} \mathrm{AlO}_{22}(\mathrm{OH})_{2}\right]$ in high and ultra-high pressure rocks from the Western Alps and China indicate that sodic amphiboles are also stable up to very high pressures $(>25-30 \mathrm{kbar})$ and temperatures $(600-$ $\left.800^{\circ} \mathrm{C}\right)$. In general, this agrees with previous experimental investigations on glaucophane (Maresch 1973, 1977; Koons 1982; Carman and Gilbert 1983; Pawley 1992; Welch and Graham 1992); however, in detail, the compositions of both the synthetic and the natural amphiboles deviate significantly from stoichiometric glaucophane. Explanations for this behavior and its implication for metamorphic conditions remain elusive.

Although there have been numerous studies of the stability of glaucophane (Ernst 1961; Maresch 1973, 1977; Koons 1982; Carman and Gilbert 1983; Pawley 1992; Welch and Graham 1992), determination of the composition of experimentally grown amphiboles has been hampered by the small grain size of the run products. Almost all previous studies used gel mixtures as starting materials and electron microprobe analyses and $\mathrm{X}$-ray diffraction (XRD) analysis suggest that the composition of the newly formed amphibole deviates significantly from glaucophane end member composition. The XRD analysis of run products by Maresch $(1973,1977)$ showed that amphibole composition from his experiments and the experiments of Ernst (1961, 1963) are also displaced in composition, probably towards $\mathrm{Na}-\mathrm{Mg}$-cummingtonite $\left(\mathrm{Na}_{2} \mathrm{Mg}_{6} \mathrm{Si}_{8} \mathrm{O}_{22}(\mathrm{OH})_{2}\right)$. Besides XRD work, only a few experimental studies on glaucophane stability in the system NMASH include electron microprobe analyses of the synthetic amphiboles (Koons 1982; Carman and Gilbert 1983; Pawley 1992) and only one study involves the systematic electron microprobe analyses of synthetic sodic amphiboles over a pressure-temperature range. Welch and Graham (1992) studied the stability of glaucophane analogs in the system $\mathrm{Na}_{2} \mathrm{O}-\mathrm{MgO}-\mathrm{Al}_{2} \mathrm{O}_{3}-\mathrm{SiO}_{2}-\mathrm{SiF}_{4}$ (NMASF) and obtained systematic electron microprobe analyses of their run products with increasing pressure from 21 to 30 kbar at $800{ }^{\circ} \mathrm{C}$. These revealed an increase of tetrahedral $\mathrm{Al}$ and $\mathrm{Na}$ on the A-site (edenite substitution) in the amphiboles with decreasing pressure. They obtained limited data on the temperature dependency over a temperature interval of $50{ }^{\circ} \mathrm{C}$ from 800 to $850{ }^{\circ} \mathrm{C}$ at $27 \mathrm{kbar}$, which also indicated an increase of edenite substitution with increasing temperature.

The synthetic amphiboles from the experimental investigations mentioned above can be described chemically in NMASH, with amphibole components glaucophane $(\mathrm{Gln})$, nyböite $(\mathrm{Nyb})$, sodium anthophyllite (Na-Anth), cummingtonite (Cm), and Al-Na-cum-
Table 1 Formulas and abbreviations of amphiboles in the NMASH system. Names and abbreviations of amphibole species in the system $\mathrm{Na}_{2} \mathrm{O}-\mathrm{MgO}-\mathrm{Al}_{2} \mathrm{O}_{3}-\mathrm{SiO}_{2}-\mathrm{H}_{2} \mathrm{O}$ (NMASH) according to Leake et al. (1997). Also shown is the distribution of the cations on the important crystallographic sites

\begin{tabular}{llllll}
\hline & $\mathrm{A}$ & $\mathrm{M}(4)$ & $\mathrm{M}(123)$ & $\mathrm{T}$ & Abbreviation \\
\hline Glaucophane & $\square$ & $\mathrm{Na}_{2}$ & $\mathrm{Mg}_{3} \mathrm{Al}_{2}$ & $\mathrm{Si}_{8}$ & $\mathrm{Gln}$ \\
Cummingtonite & $\square$ & $\mathrm{Mg}_{2}$ & $\mathrm{Mg}_{3} \mathrm{Mg}_{2}$ & $\mathrm{Si}_{8}$ & $\mathrm{Cm}$ \\
Nyböite & $\mathrm{Na}$ & $\mathrm{Na}_{2}$ & $\mathrm{Mg}_{3} \mathrm{Al}_{2}$ & $\mathrm{Si}_{7} \mathrm{Al}$ & $\mathrm{Nyb}$ \\
Al-Na-cummingtonite & $\mathrm{Na}$ & $\mathrm{NaMg}^{2}$ & $\mathrm{Mg}_{3} \mathrm{MgAl} \mathrm{Al}$ & $\mathrm{Si}_{7} \mathrm{Al}$ & $\mathrm{Al}-\mathrm{Na}-\mathrm{Cm}$ \\
Sodium anthophyllite & $\mathrm{Na}$ & $\mathrm{Mg}_{2}$ & $\mathrm{Mg}_{3} \mathrm{Mg}_{2}$ & $\mathrm{Si}_{7} \mathrm{Al}$ & $\mathrm{Na}-\mathrm{Anth}$ \\
\hline
\end{tabular}

mingtonite (Al-Na-Cm) as shown in Table 1. The names of the amphibole species are according to Leake et al. (1997). Pawley (1992) used the name Mg-kataphorite to describe a hypothetical amphibole species where $\mathrm{Ca}$ on the $\mathrm{M}(4)$ site in kataphorite is replaced by $\mathrm{Mg}$. Since kataphorite is a sodic-calcic amphibole and this present study strictly deals with sodic amphiboles, we use the hypothetical term Al-Na-cummingtonite (D. Jenkins, personal communication). Na-Anth stands for a hypothetical monoclinic end member with sodium anthophyllite composition. These amphibole species are related to each other by the substitutions $\left[\mathrm{Na}^{(\mathrm{M} 4)} \mathrm{Al}^{\mathrm{VI}}<=>\left[\mathrm{Mg}^{(\mathrm{M} 4)} \mathrm{Mg}^{\mathrm{VI}}\right]\right.$ and $\left[\square^{\mathrm{A}} \mathrm{Si}\right]<=>$ $\left[\mathrm{Na}^{\mathrm{A}} \mathrm{Al}^{\mathrm{IV}}\right]$ (Fig. 1).

It is the aim of this study (1) to perform a systematic investigation of the compositional variation of sodic amphiboles in the NMASH system at high and ultra-

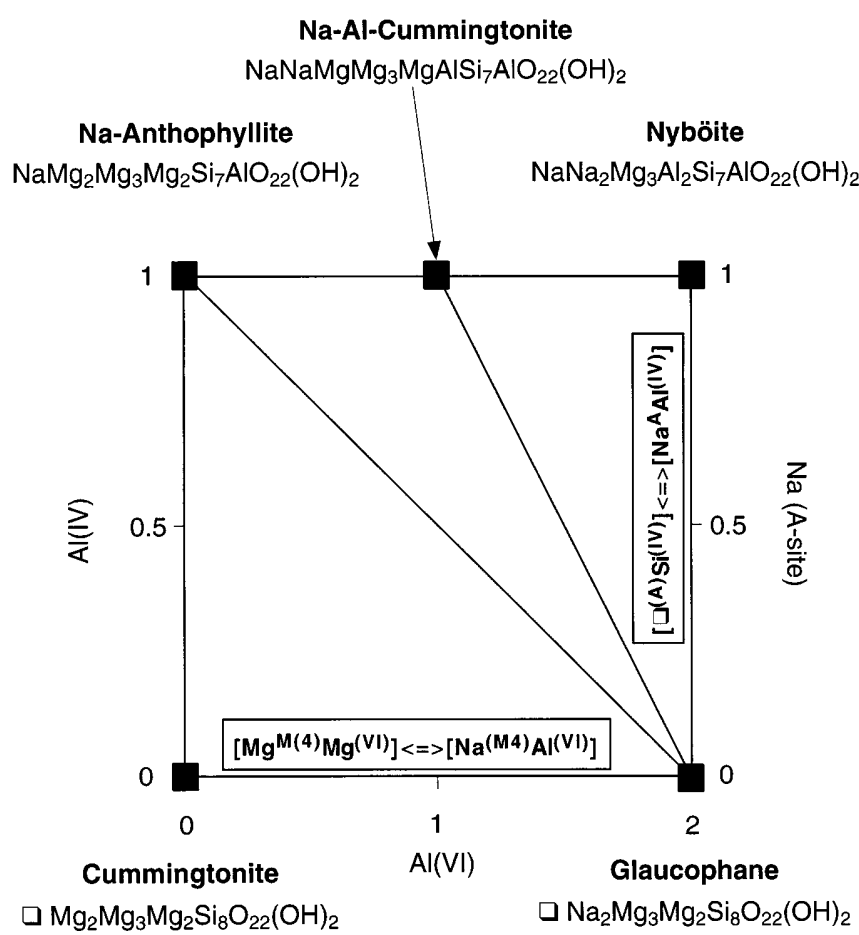

Fig. 1 The compositional relations between glaucophane, cummingtonite, nyböite, sodium anthophyllite, and Al-Na-cummingtonite expressed in terms of the two main coupled substitutions $\left[\mathrm{Na}^{\mathrm{A}} \mathrm{Al}^{\mathrm{IV}}\right]<=>\left[\square^{\mathrm{A}} \mathrm{Si}\right]$ (edenite vector) toward nyböite, and $\left[\mathrm{Mg}^{(\mathrm{M} 4)}\right.$ $\mathrm{Mg}^{\mathrm{VI}}<=>\left[\mathrm{Na}^{(\mathrm{M} 4)} \mathrm{Al}^{\mathrm{VI}}\right]$ toward cummingtonite 
high pressure conditions $\left(20-30 \mathrm{kbar}, 700-800{ }^{\circ} \mathrm{C}\right)$, (2) to use natural and synthetic minerals in the starting mixture instead of gels, and (3) to compare the results to the previous experimental investigations and to natural sodic amphiboles from ultra-high pressure terranes.

\section{Experimental and analytical methods}

We undertook piston-cylinder experiments involving glaucophane, jadeite, talc \pm quartz with seeds of natural glaucophane in the starting material. At high pressures, glaucophane stability is limited by the equilibrium:

$\mathrm{Na}_{2} \mathrm{Mg}_{3} \mathrm{Al}_{2} \mathrm{Si}_{8} \mathrm{O}_{22}(\mathrm{OH})_{2}=2 \mathrm{NaAlSi}_{2} \mathrm{O}_{6}+\mathrm{Mg}_{3} \mathrm{Si}_{4} \mathrm{O}_{10}(\mathrm{OH})_{2}$

Glaucophane $=$ Jadeite + Talc

Since this reaction is water conserving, it presents an ideal starting point for our investigation. Preliminary calculations using the database of Holland and Powell (1998) and their updated software THERMOCALC v. 2.5 indicate that reaction (1) has a shallow negative slope and lies between 35 and $36 \mathrm{kbar}$ at 700 and $800{ }^{\circ} \mathrm{C}$. However, solid solution in glaucophane will stabilize sodic amphiboles up to higher pressures, assuming constant jadeite and talc compositions and conservation of $\mathrm{H}_{2} \mathrm{O}$.

\section{Starting materials}

Natural and synthetic minerals were used as starting materials. Natural glaucophane from the Sesia-Lanzo Zone with a high Mg\# $\left[100 \mathrm{Mg} /\left(\mathrm{Mg}+\mathrm{Fe}^{2+}\right)\right]$ of 83 was used as the amphibole starting material (Table 2). The material is occasionally zoned with magnesian cores $(\mathrm{Mg} \#=83)$ and more ferroan rims $(\mathrm{Mg} \#=78)$ and often contains tiny $(<5 \mu \mathrm{m})$ inclusions of quartz, allanite, and rutile. This sample is the same as used by Gillet et al. (1989) and Robie et al. (1991) for their heat capacity measurements and determination of $S_{298}^{\circ}$ of glaucophane. The talc sample, from the mineral collection of the University of Michigan, is from Tumby Bay, South Carolina, and is almost pure $(\mathrm{Mg} \#=99.8)$ with no $\mathrm{F}$ and very little $\mathrm{Cl}(<0.03 \mathrm{wt} \%)$. Jadeite synthesized by S.R. Bohlen was also used as a starting material. All starting materials have been analyzed with electron microprobe (Table 2). The starting materials were dried overnight at $120^{\circ} \mathrm{C}$ and stoichiometric mixtures according to reaction (1) were prepared with and without excess quartz. The quartz-bearing runs contained about $10 \mathrm{wt} \%$ excess quartz to ensure Si buffering. Then the mixtures were ground in an agate mortar together with ethanol to achieve a very small grain size and high grade of sample homogenization.

\section{Run procedures}

Experiments were performed in a piston-cylinder apparatus at the Department of Earth and Space Sciences, University of California at Los Angeles (UCLA). For pressures of $20 \mathrm{kbar}, 25.4 \mathrm{~mm}$ (1 inch) diameter furnace assemblies and pistons were used. All runs above 20 kbar were performed in a $12.7 \mathrm{~mm}$ ( 0.5 inch) assembly. The furnace is made of graphite and the pressure medium is $\mathrm{NaCl}$ (Bohlen 1984; Manning and Boettcher 1994). In the 0.5inch experiments, the $\mathrm{NaCl}$ plug on the bottom was replaced by a boron nitride (BN) plug. To minimize friction between the assembly and pressure vessel, lead foil was wrapped around the furnace assembly and the cylinder walls of the pressure vessel were lubri-
Table 2 Representative electron microprobe analyses of the starting material. Formulas normalized to $24(\mathrm{O}+\mathrm{OH})$ for amphibole, $6 \mathrm{O}$ for jadeite, and $22 \mathrm{O}$ for talc. n.d. Not detected. Amphibole: natural glaucophane from Gillet et al. (1989); jadeite: synthetic jadeite from Liu and Bohlen (1995); talc: natural talc from Tumby Bay, South Carolina, from the collection of the Department of Geological Sciences, University of Michigan

\begin{tabular}{|c|c|c|c|c|c|c|}
\hline \multicolumn{3}{|c|}{ Amphibole } & \multirow{2}{*}{$\frac{\text { Jadeite }}{58.81}$} & \multicolumn{3}{|c|}{ Talc } \\
\hline $\mathrm{SiO}_{2}$ & 58.92 & 58.92 & & 59.20 & 64.49 & 63.79 \\
\hline $\mathrm{TiO}_{2}$ & 0.01 & 0.02 & n.d. & n.d. & n.d. & n.d. \\
\hline $\mathrm{Al}_{2} \mathrm{O}_{3}$ & 12.43 & 12.59 & 25.76 & 25.40 & 0.18 & 0.04 \\
\hline $\mathrm{Cr}_{2} \mathrm{O}_{3}$ & n.d. & n.d. & n.d. & n.d. & 0.02 & 0.01 \\
\hline $\mathrm{FeO}^{\mathrm{a}}$ & 5.55 & 5.68 & 0.02 & n.d. & 0.09 & 0.11 \\
\hline $\mathrm{MnO}$ & 0.06 & 0.06 & 0.02 & 0.03 & 0.03 & n.d. \\
\hline $\mathrm{MgO}$ & 12.75 & 12.63 & 0.02 & 0.02 & 30.93 & 31.08 \\
\hline $\mathrm{CaO}$ & 0.68 & 0.67 & 0.04 & 0.02 & 0.02 & 0.02 \\
\hline $\mathrm{Na}_{2} \mathrm{O}$ & 7.29 & 7.33 & 15.34 & 15.42 & 0.01 & 0.02 \\
\hline $\mathrm{K}_{2} \mathrm{O}$ & n.d. & 0.01 & n.d. & n.d. & n.d. & n.d. \\
\hline $\mathrm{H}_{2} \mathrm{O}^{\mathrm{b}}$ & 2.23 & 2.24 & n.d. & n.d. & 4.75 & 4.75 \\
\hline$\Sigma$ & 99.92 & 100.16 & 100.05 & 100.11 & 100.49 & 99.83 \\
\hline$\overline{\mathrm{Si}}$ & 7.91 & 7.90 & 1.98 & 1.99 & 8.08 & 8.06 \\
\hline $\mathrm{Al}^{(\mathrm{IV})}$ & 0.09 & 0.10 & 0.02 & 0.01 & n.d. & n.d. \\
\hline \multicolumn{7}{|c|}{$\mathrm{M}(123)$} \\
\hline $\mathrm{Al}^{(\mathrm{VI})}$ & 1.88 & 1.89 & 1.00 & 0.99 & 0.03 & 0.01 \\
\hline $\mathrm{Cr}$ & n.d. & n.d. & n.d. & n.d. & $<0.01$ & $<0.01$ \\
\hline $\mathrm{Ti}$ & $<0.01$ & $<0.01$ & n.d. & n.d. & $<0.01$ & n.d. \\
\hline $\mathrm{Fe}^{2+}$ & 0.57 & 0.59 & $<0.01$ & n.d. & 0.01 & 0.01 \\
\hline $\mathrm{Mn}$ & n.d. & n.d. & $<0.01$ & $<0.01$ & $<0.01$ & n.d. \\
\hline $\mathrm{Mg}$ & 2.55 & 2.52 & $<0.01$ & $<0.01$ & 5.78 & 5.85 \\
\hline \multicolumn{7}{|l|}{$\mathrm{M}(4)$} \\
\hline $\mathrm{Mg}$ & n.d. & n.d. & n.d. & n.d. & n.d. & n.d. \\
\hline $\mathrm{Fe}^{2+}$ & 0.05 & 0.05 & n.d. & n.d. & n.d. & n.d. \\
\hline $\mathrm{Mn}$ & 0.01 & 0.01 & n.d. & n.d. & n.d. & n.d. \\
\hline $\mathrm{Ca}$ & 0.10 & 0.10 & $<0.01$ & $<0.01$ & $<0.01$ & $<0.01$ \\
\hline $\mathrm{Na}$ & 1.84 & 1.85 & 1.00 & 1.00 & $<0.01$ & $<0.01$ \\
\hline \multicolumn{7}{|l|}{ A-site } \\
\hline $\mathrm{Na}$ & 0.05 & 0.06 & n.d. & n.d. & n.d. & n.d. \\
\hline K & n.d. & $<0.01$ & n.d. & n.d. & n.d. & n.d. \\
\hline $\mathrm{OH}$ & 2.00 & 2.00 & n.d. & n.d. & 4.00 & 4.00 \\
\hline
\end{tabular}

${ }^{\mathrm{a}} \mathrm{Fe}_{\mathrm{tot}}=\mathrm{FeO}$

${ }^{\mathrm{b}}$ Calculated 
cated with $\mathrm{MoS}_{2}$. Pressure corrections resulting from the strength of the salt cell assembly and friction between the assembly and the cylinder are negligible (Mirwald et al. 1975). Stoichiometric mixtures of the starting materials, according to reaction (1), with or without excess quartz or water, were sealed in a welded $\mathrm{Ag}_{80} \mathrm{Pd}_{20}$ capsule of $2 \mathrm{~mm}$ diameter. In some experiments, two capsules, one quartz-bearing and one quartz-absent, were placed next to each other into the assembly. The capsules were placed horizontally in the furnace and surrounded by $\mathrm{BN}$ to reduce thermal gradients (Bohlen 1984). Owing to the low Fe contents of the amphiboles, no hydrogen fugacity buffer was used, except in one experiment for comparison. Temperatures were recorded with a $\mathrm{Pt} / \mathrm{Pt}_{90} \mathrm{Rh}_{10}$ thermocouple inserted vertically through a $\mathrm{MgO}$ tube positioned on the small Pt piece resting on the sample. This geometry prevented capsule puncture by the thermocouple. The temperature uncertainty in these runs is thought to be $\pm 5^{\circ} \mathrm{C}$. Pressures were measured with a Heise gauge and the uncertainty is thought to be $\pm 0.1 \mathrm{kbar}$.

The piston-in method was used in all experiments (Johannes et al. 1971). First a pressure of approximately three-quarters of that to be maintained during the run was applied to the furnace assembly. Temperature was then increased to the desired value of the run over a period of approximately $10 \mathrm{~min}$. Finally the pressure was increased to the desired value. Run duration ranged from 84 to $408 \mathrm{~h}$, depending on the temperature and pressure conditions of the experiment (Table 3).

\section{Analytical methods}

The run products were analyzed by powder X-ray diffraction (XRD), scanning electron microscopy (SEM), electron microprobe analysis
(EMPA), and one sample was investigated with a scanning transmission electron microscope (STEM). The run products were split for powder XRD and SEM-EMPA analysis. The XRD studies were performed using a conventional Norelco-Philips vertical diffractometer with variable slit geometry. The rest of the run product was mounted in epoxy on a glass slide and subsequently polished. Electron microprobe analyses and SEM petrography were conducted with the Cameca CAMEBAX electron microprobe at UCLA. Analyses were obtained at $15 \mathrm{kV}$ and $10 \mathrm{nA}$ using a point beam. The counting time was $20 \mathrm{~s}$ for the elements $\mathrm{Si}, \mathrm{Al}, \mathrm{Mg}, \mathrm{Na}, \mathrm{Fe}$, and $\mathrm{Ca}$, and $10 \mathrm{~s}$ for additional elements, such as $\mathrm{K}, \mathrm{Mn}, \mathrm{Cr}$, and $\mathrm{Ti}$. Natural and synthetic mineral standards were used and the raw data were reduced with a PAP-type correction provided by Cameca. Analytical standards include Gotthard adularia (K), New Idria jadeite (Si, Na), synthetic spessartine (Mn), and grossular (Ca, Al), synthetic chromite $(\mathrm{Cr})$, natural hedenbergite $(\mathrm{Fe})$, synthetic sphene (Ti), and Marjalahti olivine $(\mathrm{Mg})$. Mineral formulas were calculated with the program MINFILE (Afifi and Essene 1988). Scanning electron microscopy was also performed with the Cameca CAMEBAX electron microprobe at UCLA.

Sample preparation for STEM was done by grinding the run product in an agate mortar in methanol. This led to the suspension of disaggregated crystals, which were mounted onto a holeycarbon $\mathrm{Cu}$ grid by dipping it into the solution. Afterwards the sample was carbon coated. The STEM observations were obtained at the Department of Geological Sciences at the University of Michigan, using a Philips CM12 STEM, fitted with a Kevex Quantum solid state detector. The STEM was operated at an accelerating voltage of $120 \mathrm{kV}$ and a beam current of ca. $10 \mathrm{nA}$ to obtain bright field images and selected-area electron diffraction (SAED) patterns.
Table 3 Run conditions and results. Amp Amphibole; Jd jadeite; Tlc talc; En enstatite; $Q t z$ quartz; Coe coesite; $M g s$ magnesite; 15 A phase Na-phyllosilicate; all abbreviations according to Kretz (1983)

\begin{tabular}{|c|c|c|c|c|c|}
\hline & Run no. & $P$ (kbar) & $T\left({ }^{\circ} \mathrm{C}\right)$ & Hours & Phases observed \\
\hline \multicolumn{6}{|l|}{ GJT experiments } \\
\hline $\mathrm{Jd}+\mathrm{Tlc}, \mathrm{Gln}$ & 9 & 20 & 700 & 84 & Amp, Jd, Tlc, Qtz \\
\hline $\mathrm{Gln}+\mathrm{Jd}+\mathrm{Tlc}+\mathrm{H}_{2} \mathrm{O}$ & 4 & 20 & 700 & 84 & $\begin{array}{l}\text { Amp, Jd, Tlc, } \\
15 \text { A phase, Qtz }\end{array}$ \\
\hline $\mathrm{Gln}+\mathrm{Jd}+\mathrm{Tlc}$ & 3 & 20 & 700 & 84 & Amp, Jd, Tlc, Qtz \\
\hline $\mathrm{Gln}+\mathrm{Jd}+\mathrm{Tlc}$ & 90 & 20 & 750 & 108 & Amp, Jd, Tlc, Qtz \\
\hline $\mathrm{Gln}+\mathrm{Jd}+\mathrm{Tlc}$ & 136 & 25 & 700 & 408 & Amp, Jd, Tlc, Qtz \\
\hline $\mathrm{Gln}+\mathrm{Jd}+\mathrm{Tlc}$ & 95 & 25 & 750 & 120 & Amp, Jd, Tlc, Qtz \\
\hline $\mathrm{Gln}+\mathrm{Jd}+\mathrm{Tlc}$ & 40 & 25 & 800 & 96 & Amp, Jd, En, Qtz \\
\hline $\mathrm{Gln}+\mathrm{Jd}+\mathrm{Tlc}$ & 52 & 30 & 700 & 120 & Amp, Jd, Tlc, Coe \\
\hline $\mathrm{Gln}+\mathrm{Jd}+\mathrm{Tlc}$ & 55 & 30 & 750 & 156 & Amp, Jd, Coe, Tlc \\
\hline $\mathrm{Gln}+\mathrm{Jd}+\mathrm{Tlc}$ & 44 & 30 & 800 & 132 & Amp, Jd, En, Coe \\
\hline \multicolumn{6}{|l|}{ GJTQ experiments } \\
\hline $\mathrm{Gln}+\mathrm{Jd}+\mathrm{Tlc}+\mathrm{Qtz}$ & 8 & 20 & 700 & 84 & Amp, Jd, Tlc, Qtz \\
\hline $\mathrm{Gln}+\mathrm{Jd}+\mathrm{Tlc}+\mathrm{Qtz}$ & 86 & 20 & 750 & 108 & Amp, Jd, Qtz, Tlc \\
\hline $\mathrm{Gln}+\mathrm{Jd}+\mathrm{Tlc}+\mathrm{Qtz}$ & 16 & 25 & 700 & 408 & Amp, Jd, Tlc, Qtz \\
\hline $\mathrm{Gln}+\mathrm{Jd}+\mathrm{Tlc}+\mathrm{Qtz}$ & 93 & 25 & 750 & 120 & Amp, Jd, Qtz, Tlc \\
\hline $\mathrm{Gln}+\mathrm{Jd}+\mathrm{Tlc}+\mathrm{Qtz}$ & 94 & 25 & 800 & 96 & Amp, Jd, En, Qtz \\
\hline $\mathrm{Gln}+\mathrm{Jd}+\mathrm{Tlc}+\mathrm{Qtz}+\mathrm{H}_{2} \mathrm{O}$ & 179 & 30 & 700 & 408 & $\begin{array}{c}\text { Amp, Jd, Tlc, Coe, } \\
15 \AA \text { phase }\end{array}$ \\
\hline $\mathrm{Gln}+\mathrm{Jd}+\mathrm{Tlc}+\mathrm{Qtz}$ & 97 & 30 & 750 & 120 & Amp, Jd, Coe, Tlc \\
\hline $\mathrm{Gln}+\mathrm{Jd}+\mathrm{Tlc}+\mathrm{Qtz}$ & 98 & 30 & 800 & 96 & Amp, Jd, En, Coe \\
\hline \multicolumn{6}{|l|}{ Run duration experiments } \\
\hline $\mathrm{Gln}+\mathrm{Jd}+\mathrm{Tlc}+\mathrm{Qtz}$ & 195 & 20 & 750 & 48 & $\begin{array}{l}\text { Amp, Jd, En, Mgs, } \\
15 \AA \text { phase, Tlc, Qtz }\end{array}$ \\
\hline $\mathrm{Gln}+\mathrm{Jd}+\mathrm{Tlc}+\mathrm{Qtz}$ & 86 & 20 & 750 & 108 & Amp, Jd, Tlc, Qtz \\
\hline $\mathrm{Gln}+\mathrm{Jd}+\mathrm{Tlc}+\mathrm{Qtz}$ & 169 & 20 & 750 & 264 & Amp, Jd, En, Tlc, Qtz \\
\hline \multicolumn{6}{|l|}{ Re-equilibration experiments } \\
\hline \multirow[t]{2}{*}{$\mathrm{Gln}+\mathrm{Jd}+\mathrm{Tlc}$} & 168 & 20 & 750 & 288 & Amp, Jd, En, Tlc, Qtz \\
\hline & & 20 & 700 & 384 & Amp, Jd, En, Tlc, Qtz \\
\hline \multirow[t]{2}{*}{$\mathrm{Gln}+\mathrm{Jd}+\mathrm{Tlc}$} & 166 & 20 & 750 & 288 & Amp, Jd, En, Tlc, Qtz \\
\hline & & 25 & 750 & 240 & Amp, Jd, En, Tlc, Qtz \\
\hline
\end{tabular}




\section{Results}

Runs were made at $5 \mathrm{kbar}$ and $50{ }^{\circ} \mathrm{C}$ increments, starting at $700{ }^{\circ} \mathrm{C}$ and $20 \mathrm{kbar}$, resulting in a total of eight distinct pressure-temperature conditions (Fig. 2). No run was performed at $800{ }^{\circ} \mathrm{C}$ and $20 \mathrm{kbar}$ because it is outside the stability field of jadeite + quartz (Fig. 2). All participating phases in the runs were checked with scanning electron microscopy to infer reaction directions. Powder XRD was mostly used for runs that contained excess $\mathrm{H}_{2} \mathrm{O}$ to check for the presence of $\mathrm{Na}$-phyllosilicates, which showed a distinct peak at low $2 \Theta$ in the pattern.

\section{$\mathrm{H}_{2} \mathrm{O}$-free runs}

The use of excess $\mathrm{H}_{2} \mathrm{O}$ as a catalyst in the experiments results in two major problems:

1. Many previous experimental investigations (Maresch 1973, 1977; Koons 1982; Carman and Gilbert 1983)

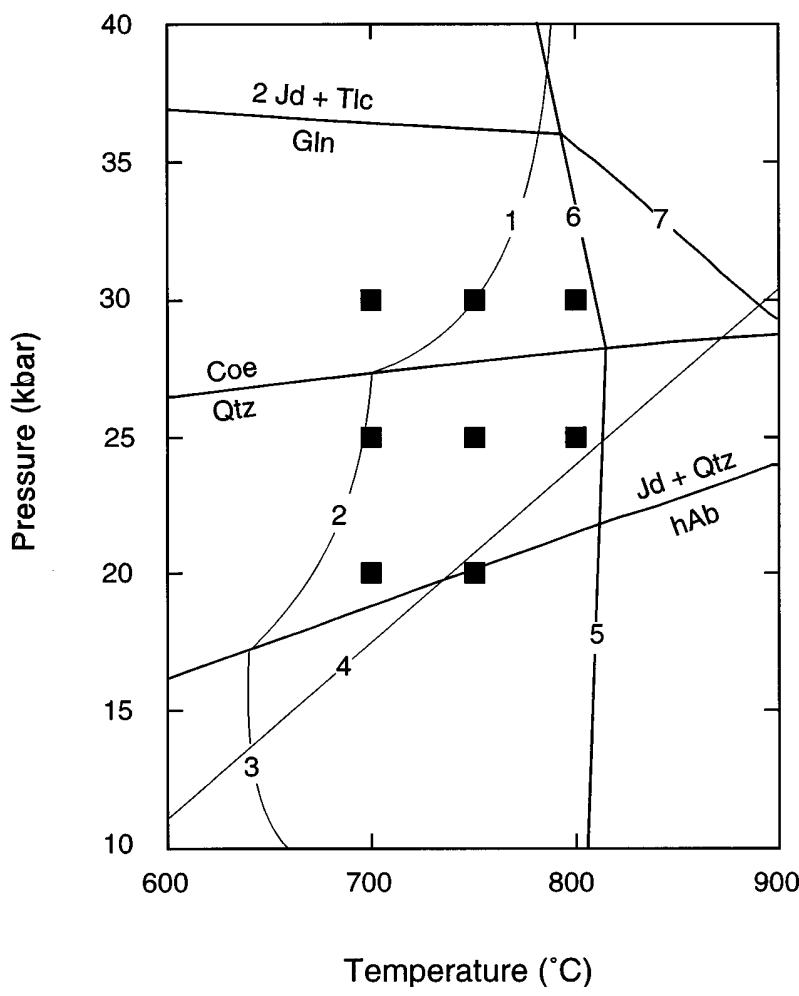

Fig. 2 Pressure-temperature grid of the experimental conditions. The black boxes indicate the experimental conditions of the runs. (1) $\mathrm{Jd}+\mathrm{Coe}+\mathrm{H}_{2} \mathrm{O}=\mathrm{L}$; (2) $\mathrm{Jd}+\mathrm{Qtz}+\mathrm{H}_{2} \mathrm{O}=\mathrm{L}$; (3) $\mathrm{Ab}+$ Qtz $+\mathrm{H}_{2} \mathrm{O}=\mathrm{L}$; (4) $\mathrm{Jd}+\mathrm{H}_{2} \mathrm{O}=\mathrm{L} ; \mathrm{hAb}=\mathrm{Jd}+\mathrm{Qtz}$ (Holland 1980); (5) $2 \mathrm{Tlc}=3 \mathrm{En}+2 \mathrm{Qtz}+2 \mathrm{H}_{2} \mathrm{O} ;(6) 2 \mathrm{Tlc}=3 \mathrm{En}+2 \mathrm{Coe}+$ $2 \mathrm{H}_{2} \mathrm{O}$; (7) $2 \mathrm{Gln}=4 \mathrm{Jd}+3 \mathrm{En}+2 \mathrm{Coe}+2 \mathrm{H}_{2} \mathrm{O}$. Reactions (1), (2), (3) and (4) are from Boettcher and Wyllie (1969); Qtz = Coe (Bohlen and Boettcher 1982); reactions (5), (6), (7), and Gln $=2 \mathrm{Jd}+$ Tlc are calculated with the program THERMOCALC v. 2.5 (Holland and Powell 1998). Gln Glaucophane; $J d$ jadeite; Tlc talc; Coe coesite; $Q t z$ quartz; $h A b$ high albite; $A b$ : albite; $E$ : enstatite; $L$ melt used excess $\mathrm{H}_{2} \mathrm{O}$ to increase reaction rates, but it led to the formation of a metastable Na-phyllosilicate.

2. Boettcher and Wyllie (1969) investigated the phase relations in the system $\mathrm{NaAlSiO}_{4}-\mathrm{SiO}_{2}-\mathrm{H}_{2} \mathrm{O}$ up to $35 \mathrm{kbar}$ and showed that addition of $\mathrm{H}_{2} \mathrm{O}$ results in the formation of melts (Fig. 2).

Because of these problems, two sets of water-absent glaucophane-jadeite-talc experiments were performed at $20-30 \mathrm{kbar}$ and $700-800{ }^{\circ} \mathrm{C}$ : quartz-bearing (GJTQ) and quartz-absent (GJT). The addition of quartz to one set of experiments was thought to be necessary after reviewing microprobe analyses of synthetic sodic amphiboles from the experimental investigations by Pawley (1992) and Welch and Graham (1992). Their results showed a significant amount of tetrahedral Al, suggesting that $\mathrm{Si}$-undersaturation promotes $\mathrm{Al}^{\mathrm{IV}}$ substitution in sodic amphibole. Most runs were performed with stoichiometric mixtures of glaucophane, jadeite, and talc under $\mathrm{H}_{2} \mathrm{O}$-absent conditions to minimize the growth of Na-phyllosilicates or formation of melts. The newly grown amphiboles form 3-10- $\mu \mathrm{m}$-wide rims around the starting glaucophane crystals, or sometimes they seem to replace the glaucophane from the starting mixture (Fig. 3A). These rims are wide enough to obtain reliable electron microprobe analyses. Only a few experiments were hampered by very low yields. This affected mostly the experiments at $700{ }^{\circ} \mathrm{C}$ and 25 and $30 \mathrm{kbar}$. The experiment at $700{ }^{\circ} \mathrm{C}, 30 \mathrm{kbar}$, was subsequently re-run for $408 \mathrm{~h}$, but no newly formed amphiboles were found in the GJT experiment and only a very minor yield was found in the GJTQ experiment. In one experiment (run no. 9) a stoichiometric mixture of jadeite and talc with a few seeds of glaucophane was used. In all runs the modal amount of talc and jadeite strongly decreases due to the formation of amphiboles. In many runs above $750{ }^{\circ} \mathrm{C}$, the amount of talc decreased rapidly and in some of the runs at 750 and $800^{\circ} \mathrm{C}$, talc completely disappeared, or partially reacted to form enstatite and quartz/coesite (Table 3).

\section{$\mathrm{H}_{2} \mathrm{O}$-bearing runs}

Only two runs contained excess $\mathrm{H}_{2} \mathrm{O}$ (ca. $10 \mathrm{wt} \%$ ultrapure $\mathrm{H}_{2} \mathrm{O}$ ). One GJT experiment (run no. 4) was performed at $700{ }^{\circ} \mathrm{C}$ and $20 \mathrm{kbar}$ where $\mathrm{H}_{2} \mathrm{O}$ was added to the starting material to investigate the extent of $\mathrm{Na}$ phyllosilicate growth, and the GJTQ experiment (run no. 179) was run at $700{ }^{\circ} \mathrm{C}$ and $30 \mathrm{kbar}$ where the presence of $\mathrm{H}_{2} \mathrm{O}$ was intended to increase the amphibole growth rate. The Na-phyllosilicate shows a distinct peak at $6.01^{\circ} 2 \Theta$ in the XRD pattern, which corresponds to a $\mathrm{d}$-value of $14.701 \AA$. This is similar to the d-value of the synthetic sodium phlogopite (14.868 $\AA$ ) synthesized by Carman (1974). This phase has already been observed in the experiments by Maresch (1977) and Koons (1982), but due to its fine-grained nature, no reliable electron microprobe analysis has been obtained. The textures in run no. 4 are very similar to the $\mathrm{H}_{2} \mathrm{O}$-free runs and the 
newly grown amphiboles generally mimic the monoclinic symmetry of the starting material (Fig. 3B), but the modal amount of Na-sheet silicates ( $15 \AA$ phase) in the matrix increases in these runs. Despite adding $\mathrm{H}_{2} \mathrm{O}$ to run no. 179, only a very small amount of amphibole overgrowth occurred, whereas abundant Na-phyllosilicate formed in the experiment.

\section{Equilibrium constraints}

We evaluated the degree to which equilibrium was approached by: (1) utilizing different run times to characterize compositional changes with time, (2) performing compositional reversals, and (3) examining the microstructure of the newly grown amphiboles in one sample by STEM for the presence of chain-multiplicity faults or other structural defects.
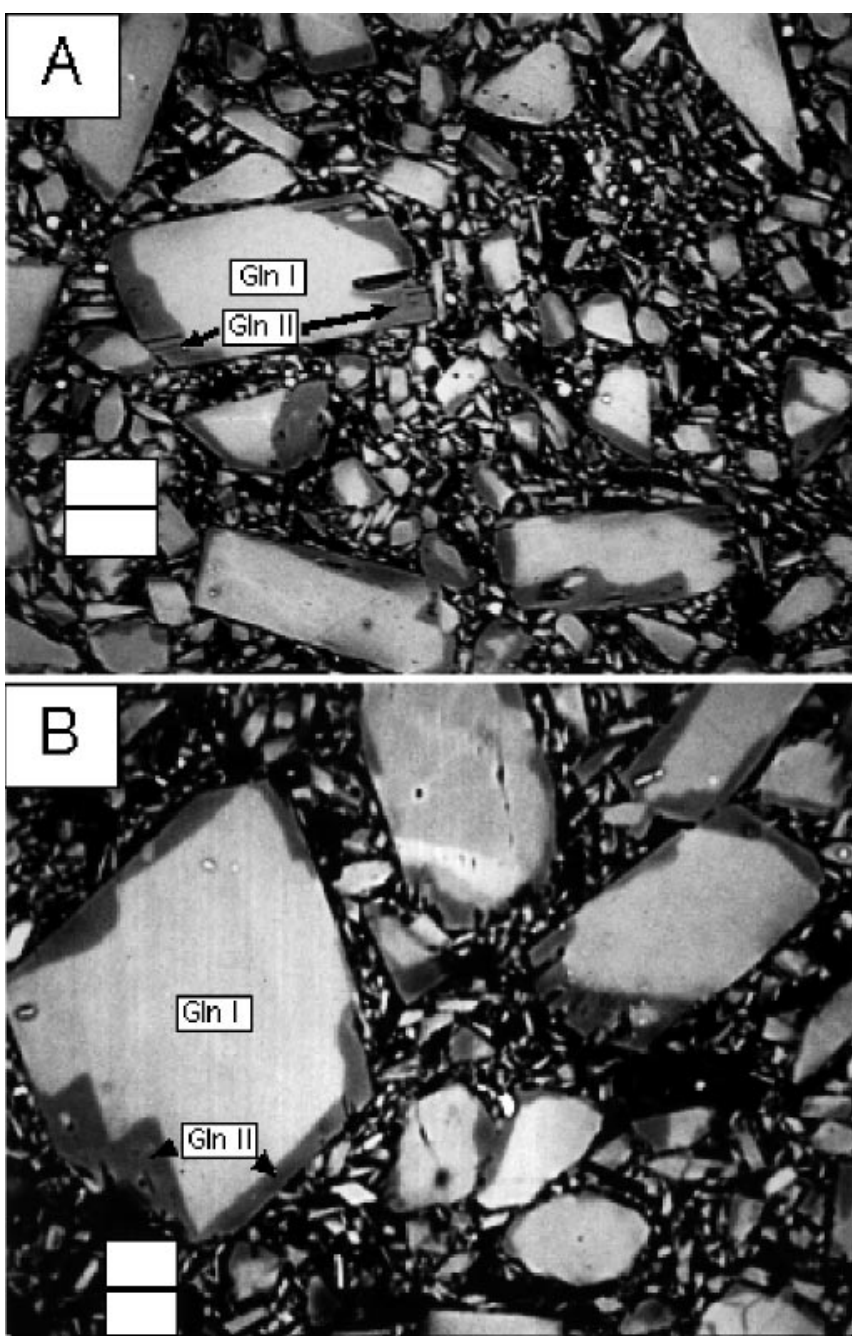

Fig. 3 A,B Back-scattered electron images of some run products from experiments at $20 \mathrm{kbar}$ and $700^{\circ} \mathrm{C}$. A Run no. 3 glaucophane + jadeite + talc; newly formed amphibole (Gln II) grows around glaucophane seeds $(G \ln I)$ and also seems to replace them, scale bar is $10 \mu \mathrm{m}$. B Run no. 4 glaucophane $(G \ln l)+$ jadeite + talc $+\mathrm{H}_{2} \mathrm{O}$, the new amphibole (Gln II) mimics the monoclinic symmetry of the starting glaucophane, scale bar is $10 \mu \mathrm{m}$

\section{Run times}

Different run times were applied to GJTQ experiments at $750{ }^{\circ} \mathrm{C}$ and $20 \mathrm{kbar}$ and the results can be seen in Fig. $4 \mathrm{~A}-\mathrm{D}$. The $\mathrm{Al}^{\mathrm{IV}}$, total $\mathrm{Al}$, total $\mathrm{Mg}$, and $\mathrm{Na}^{\mathrm{A}}$
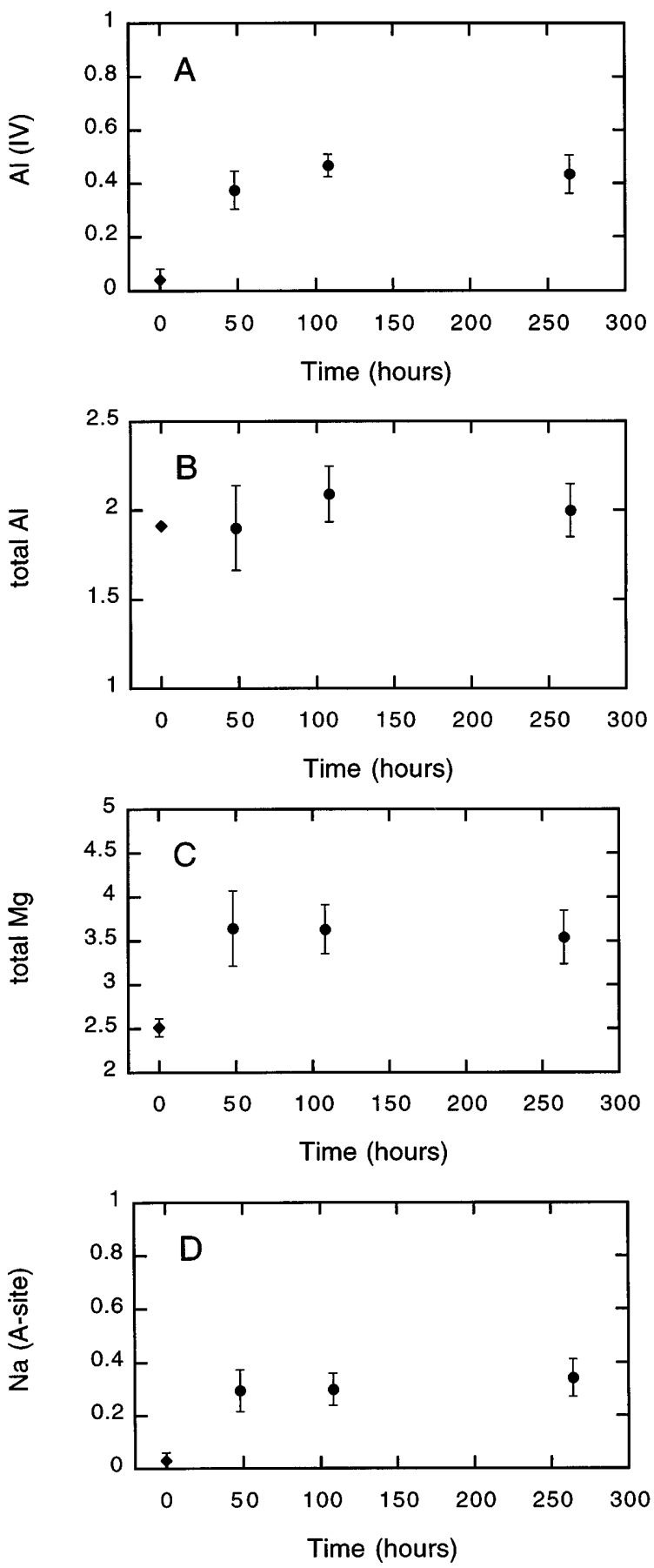

Fig. 4 A-D Plot of compositional variables in amphibole versus time in GJT experiments at $20 \mathrm{kbar}$ and $750{ }^{\circ} \mathrm{C}$. The black circles show the compositions of the synthetic amphiboles from the experiments at 48 (run no. 195), 108 (run no. 86), and 264 (run no. 169) h, the black diamonds show the composition of the starting amphibole; $\mathbf{A ~} \mathrm{Al}^{\mathrm{IV}}$ versus time; $\mathbf{B} \mathrm{Al}$ total versus time; $\mathbf{C ~} \mathbf{M g}$ total versus time; $\mathbf{D} \mathrm{Na}^{\mathrm{A}}$ versus time. The error bars are one standard deviation $(1 \sigma)$ and are omitted if $1 \sigma$ is smaller than the symbol 
content of the amphibole hardly change with time above $110 \mathrm{~h}$, but $\mathrm{Al}^{\mathrm{IV}}$ and total $\mathrm{Al}$ decrease below $110 \mathrm{~h}$, although the scatter in total $\mathrm{Al}$ and $\mathrm{Al}^{(\mathrm{IV})}$ as well does not permit a clear conclusion (Fig. 4B). The compositions of the 48-h run also show the largest variations in total $\mathrm{Al}$ and total $\mathrm{Mg}$ content (Fig. 4B, C). Run times on the order of $100 \mathrm{~h}$ are indicated to better approach equilibrium compositions. The amphiboles in these experiments do not have a sharp boundary between the starting amphibole and the newly grown rim, indicating a possible diffusive re-equilibration between the two amphiboles. The latter feature was also frequently observed in the experiments at 750 and $800{ }^{\circ} \mathrm{C}$.

\section{Compositional reversals}

The experimental results from run times above $100 \mathrm{~h}$ reveal that the amphibole composition does not change significantly, and therefore it needs to be determined whether or not these amphiboles have approached equilibrium. Therefore, two compositional reversal experiments were performed (Fig. 5A-D). Compositional reversals, whereby two disparate mineral compositions converge to a common composition, were obtained in this study down to a temperature of $700{ }^{\circ} \mathrm{C}$. One GJT experiment was run at $20 \mathrm{kbar}$ at $750{ }^{\circ} \mathrm{C}$ for $288 \mathrm{~h}$ and then at $700{ }^{\circ} \mathrm{C}$ for another $384 \mathrm{~h}$ (Fig. 5A, B), and the other GJT experiment was also run at $750{ }^{\circ} \mathrm{C}$ at $20 \mathrm{kbar}$ for $288 \mathrm{~h}$ and then at $25 \mathrm{kbar}$ for another $240 \mathrm{~h}$ (Fig. 5C, D). Figure 5A, B shows that the amphiboles re-equilibrated at $700{ }^{\circ} \mathrm{C}$, which is indicated by the overlap of the $\mathrm{Al}^{\mathrm{IV}}$ and $\mathrm{Na}^{\mathrm{A}}$ values with the values from a previous experiment at $700{ }^{\circ} \mathrm{C}$ (run no. 3). The agreement of these values, obtained after running for $384 \mathrm{~h}$, with data from run no. 3 , which lasted $84 \mathrm{~h}$, suggests that the equilibrium composition was obtained in the 84-h experiment. This is important since these are the lowest pressure and temperature conditions of the investigation where one would expect the greatest chance of disequilibrium. Figure 5C, D shows that the $\mathrm{Al}^{\mathrm{IV}}$ and $\mathrm{Na}^{\mathrm{A}}$ values of amphiboles run at $20 \mathrm{kbar}$ and then at $25 \mathrm{kbar}$ are in very good agreement with the values obtained from a previous experiment at $25 \mathrm{kbar}$. These data indicate that the amphibole compositions are probably close to equilibrium compositions, although small variations in parameters such as $\mathrm{Na}^{\mathrm{A}}$ might still occur.

Fig. 5 Results of the compositional reversals at constant pressure of $20 \mathrm{kbar}$ (A, B; run no. 168) and constant temperature of $750{ }^{\circ} \mathrm{C}(\mathbf{C}$, $\mathbf{D}$; run no. 166). $\mathbf{A ~ A l}{ }^{\text {iV }}$ in amphibole data; the open circles show the data from the experiment at $700{ }^{\circ} \mathrm{C}$ and the filled diamonds show the data from the experiment at $750{ }^{\circ} \mathrm{C}$. The filled circles show the data from an experiment, which was first run at $750{ }^{\circ} \mathrm{C}$ and subsequently at $700{ }^{\circ} \mathrm{C} ; \mathbf{B ~ N a}{ }^{\mathrm{A}}$ data; the symbols are the same as described in $\mathbf{A} ; \mathbf{C}$ $\mathrm{Al}^{\mathrm{IV}}$ data; the open circles show the data from the experiment at $25 \mathrm{kbar}$ and the filled diamonds show the data from the experiment at $20 \mathrm{kbar}$. The filled circles show the data from an experiment, which was first run at $20 \mathrm{kbar}$ and subsequently at $25 \mathrm{kbar}$; $\mathbf{D ~ N a}{ }^{\mathrm{A}}$ data; the symbols are the same as described in $\mathbf{A}$

\section{Amphibole microstructure}

One sample (run no. $3,700{ }^{\circ} \mathrm{C}, 20 \mathrm{kbar}$ ) was examined by using STEM to evaluate the possibility of wide-chain structures, intergrown with the synthetic amphiboles. This sample was chosen because if any amphiboles show
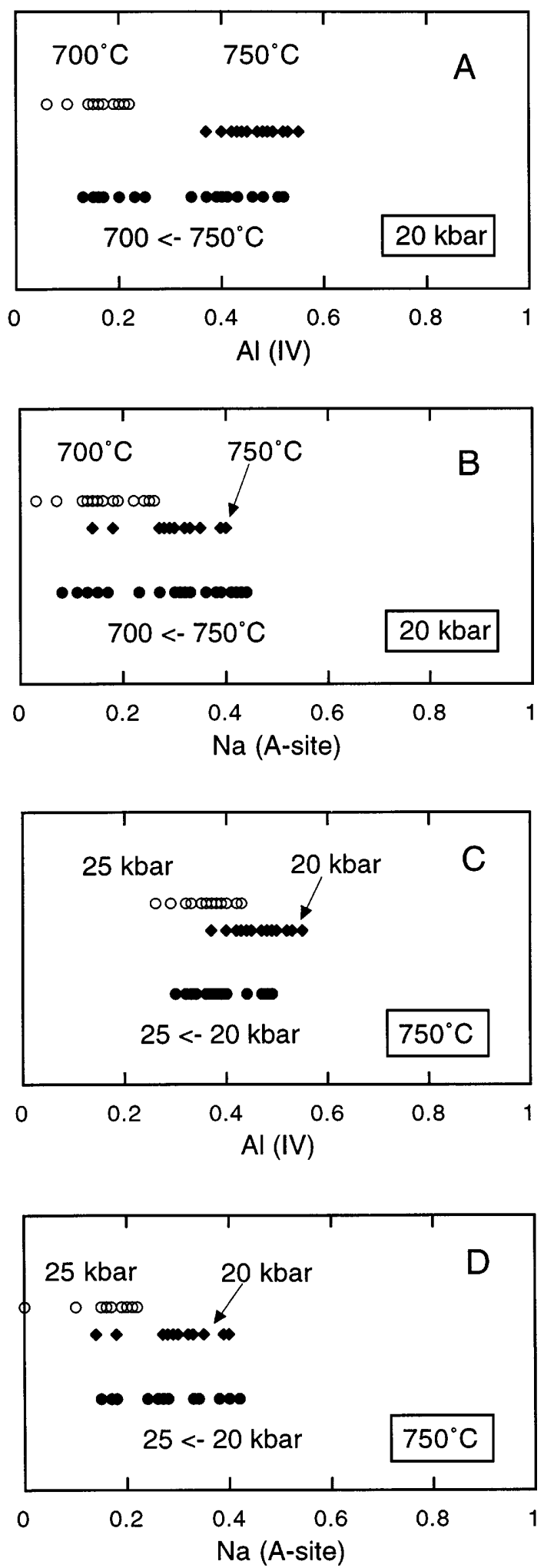
wide-chain intergrowths it should be those grown at the lowest pressures and temperatures.

The images and diffraction patterns were obtained at the rim of the amphibole crystals. To avoid beam damage, energy dispersive analysis (EDS) for composition was performed after imaging. The orientation of the selected area electron diffraction (SAED) pattern of the newly formed amphibole is $\mathrm{b}^{*}-\mathrm{c}^{*}$ and shows minimal streaking (Fig. 6A). It was assumed that the cell dimensions of the synthetic amphiboles are similar to the cell dimensions of natural glaucophane and therefore the labels and indices of the diffraction pattern are based on the refined cell dimensions of the glaucophane in the starting mixture, which were derived by a powder refinement. The program MINLAB (W.A. Dollase, personal communication) was used to obtain the cell dimensions. The space group is $\mathrm{C} 2 / \mathrm{m}$ and the cell dimensions $( \pm 2 \sigma)$ are a: $9.5287(0.0013) \AA, b: 17.7234$ (0.0025) $\AA$, c: $5.2988(0.001) \AA, \beta: 103.653(0.014)^{\circ} \AA$, and the unit-cell volume is $869.588(0.14) \AA^{3}$. These data were used to generate the Miller indices.

Our STEM data show minimal streaking along $b^{*}$. Figure $6 \mathrm{~B}$ shows a bright field image of the same area. The synthetic amphibole shows a lattice fringe with a constant thickness of ca. $9 \AA$ which is typical for glau-
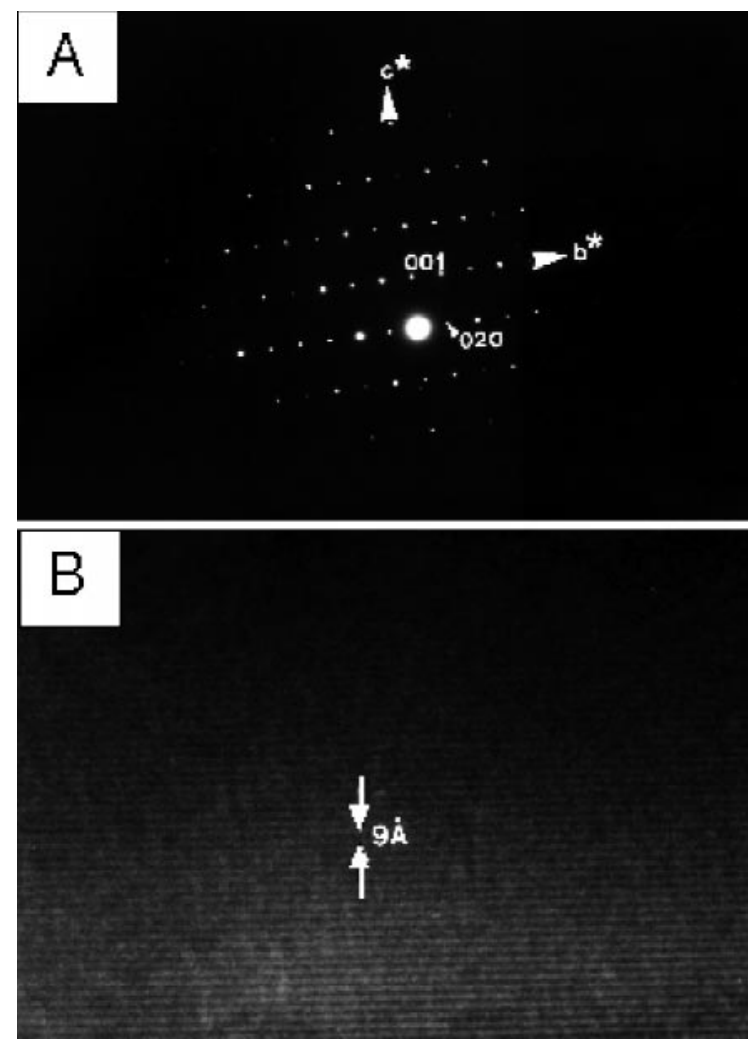

Fig. 6 A,B STEM images of a synthetic amphibole from an experiment at $700{ }^{\circ} \mathrm{C}$ and $20 \mathrm{kbar}$ (run no. 3). A Selected area electron diffraction pattern (SAED) of the synthetic amphibole showing the $\mathrm{c}^{*}-\mathrm{b}^{*}$ directions of the reciprocal lattice and labels of the (001) and (020) reflections. B Bright field image of the same area, showing the lattice fringes of the synthetic amphibole cophane. Wide-chain complexities appear to be minimal. These observations are similar to results from other STEM investigations on synthetic sodic amphiboles. The STEM data on synthetic glaucophane from Koons (1982) show that the amphiboles from his study are well crystallized and contain only few wide-chain intergrowths. Additional STEM data on synthetic richterite are reported by Pawley et al. (1993). These synthetic amphiboles show no wide-chain complexities at all. Although synthetic amphiboles contain more wide-chain intergrowths than their natural counterparts, synthetic sodic amphiboles contain fewer stacking faults than amphiboles from other systems (Maresch and Czank 1983).

\section{Compositions of the newly grown amphiboles}

The chemical compositions of representative amphibole analyses from each experiment are shown in Tables 4 and 5. The amphibole formulas were calculated on the basis of $24(\mathrm{O}+\mathrm{OH})$. The program MINFILE (Afifi and Essene 1988) assumes that the $\mathrm{M}(1,2,3)$ sites are filled with $\mathrm{Al}, \mathrm{Mg}$, and, if possible, $\mathrm{Fe}^{2+}$. The $\mathrm{Na}, \mathrm{Mn}$, and remaining $\mathrm{Mg}$ and $\mathrm{Fe}^{2+}$ are on the $\mathrm{M}(4)$ site. All Fe was considered $\mathrm{Fe}^{2+}$.

The newly grown amphiboles deviate significantly from stoichiometric glaucophane. Compared to the formula for ideal glaucophane, $\square \mathrm{Na}_{2} \mathrm{Mg}_{3} \mathrm{Al}_{2} \mathrm{Si}_{8} \mathrm{O}_{22}(\mathrm{OH})_{2}$, the synthetic amphiboles show considerable $\mathrm{Al}^{\mathrm{IV}}$ substitution for $\mathrm{Si}(0.1-0.6 \mathrm{apfu})$ and the sum of total $\mathrm{Al}$ varies from 1.7 to 2.8 apfu and in most cases exceeds 2 . The amphiboles also show an excess of $\mathrm{Mg}$ over ideal glaucophane: it varies between 3 and 4 apfu. The sum of total $\mathrm{Na}$ is in most cases lower than 2(1.2-2.1 apfu), and considerable amounts of $\mathrm{Mg}$ and $\mathrm{Fe}^{2+}(<0.4 \mathrm{apfu})$ are on $\mathrm{M}(4)$. The A-site has up to $0.5 \mathrm{Na}$ apfu.

Compositional variations with increasing pressure and temperature

As illustrated in Tables 4 and 5 and Fig. 7, amphibole compositions in the GJT and GJTQ experiments vary strongly with both pressure and temperature.

\section{Si}

The Si content of the amphiboles increases strongly in both sets of experiments with increasing pressure at 750 and $800{ }^{\circ} \mathrm{C}$ (Fig. 7A, E), but shows almost no variation at $700{ }^{\circ} \mathrm{C}$ in the GJT experiments. In the GJTQ experiments there is a strong increase in $\mathrm{Si}$ in the experiments at $30 \mathrm{kbar}$. The Si content also decreases with increasing temperature at all pressures (Fig. 7A, E).

\section{Al}

The total $\mathrm{Al}$ content decreases with increasing pressure at 750 and $800{ }^{\circ} \mathrm{C}$ and remains constant at $700{ }^{\circ} \mathrm{C}$ 
Table 4 Average electron microprobe analyses of amphibole from the GJT experiments. Formulas normalized to $24(\mathrm{O}+\mathrm{OH})$; n.d. Not detected; numbers in parentheses are $1 \sigma$ standard deviation. Since the program MINFILE assigns $\mathrm{Mg}$ and $\mathrm{Al}$ to the $\mathrm{M}(123)$ sites, without considering the $\mathrm{Fe}^{2+} / \mathrm{Mg}$ ratio of the amphiboles, $\mathrm{Fe}^{2+}$ is mostly distributed to the M(4) site. Due to the small $\mathrm{Fe}^{2+}$ contents, no partitioning between the $\mathbf{M}(1,2,3)$ and $\mathbf{M}(4)$ sites, according to the $\mathrm{Fe}^{2+} / \mathrm{Mg}$ ratio, was calculated

\begin{tabular}{|c|c|c|c|c|c|c|c|c|}
\hline $\begin{array}{l}\mathrm{T}\left({ }^{\circ} \mathrm{C}\right) \\
\mathrm{P} \text { (kbar) } \\
\text { Run no. } \\
n\end{array}$ & $\begin{array}{r}700 \\
20 \\
3 \\
21\end{array}$ & $\begin{array}{r}700 \\
25 \\
136 \\
11\end{array}$ & $\begin{array}{l}700 \\
30 \\
52 \\
9\end{array}$ & $\begin{array}{r}750 \\
20 \\
90 \\
22\end{array}$ & $\begin{array}{l}750 \\
25 \\
95 \\
18\end{array}$ & $\begin{array}{l}750 \\
30 \\
55 \\
14\end{array}$ & $\begin{array}{l}800 \\
25 \\
40 \\
17\end{array}$ & $\begin{array}{l}800 \\
30 \\
44 \\
15\end{array}$ \\
\hline $\begin{array}{l}\mathrm{SiO}_{2} \\
\mathrm{TiO}_{2} \\
\mathrm{Al}_{2} \mathrm{O}_{3} \\
\mathrm{Cr}_{2} \mathrm{O}_{3} \\
\mathrm{FeO}^{\mathrm{a}} \\
\mathrm{MnO} \\
\mathrm{MgO} \\
\mathrm{CaO} \\
\mathrm{Na}_{2} \mathrm{O} \\
\mathrm{K}_{2} \mathrm{O} \\
\mathrm{H}_{2} \mathrm{O}^{\mathrm{b}} \\
\sum \\
\mathrm{Si} \\
\mathrm{Al}^{(\mathrm{IV})}\end{array}$ & $\begin{array}{r}59.52(40) \\
0.03(04) \\
12.57(66) \\
0.03(03) \\
1.56(33) \\
0.02(02) \\
16.37(97) \\
0.15(09) \\
7.74(28) \\
0.02(02) \\
2.28(01) \\
100.27(56) \\
7.83(04) \\
0.17(04)\end{array}$ & $\begin{array}{c}58.20(69) \\
0.02(02) \\
11.79(65) \\
0.01(01) \\
4.61(39) \\
0.02(02) \\
16.03(89) \\
0.35(04) \\
6.37(43) \\
0.05(02) \\
2.24(02) \\
99.68(103) \\
7.80(04) \\
0.20(04)\end{array}$ & $\begin{array}{r}58.27(34) \\
0.10(08) \\
11.55(50) \\
0.04(03) \\
4.28(43) \\
0.03(03) \\
15.54(65) \\
0.66(09) \\
6.26(24) \\
0.02(01) \\
2.23(01) \\
98.99(43) \\
7.85(04) \\
0.15(04)\end{array}$ & $\begin{array}{c}56.37(62) \\
0.03(02) \\
14.21(66) \\
0.03(03) \\
2.64(44) \\
0.03(03) \\
17.52(140) \\
0.17(07) \\
6.81(57) \\
0.01(01) \\
2.25(02) \\
100.07(71) \\
7.49(06) \\
0.51(06)\end{array}$ & $\begin{array}{c}56.96(64) \\
0.03(02) \\
13.33(46) \\
\text { n.d. } \\
3.77(43) \\
0.10(02) \\
16.23(88) \\
0.27(08) \\
6.53(57) \\
\text { n.d. } \\
2.24(01) \\
99.46(61) \\
7.64(06) \\
0.36(06)\end{array}$ & $\begin{array}{r}57.66(53) \\
0.15(15) \\
11.94(44) \\
0.06(05) \\
4.20(35) \\
0.05(02) \\
15.72(97) \\
0.54(08) \\
6.59(36) \\
0.01(01) \\
2.23(01) \\
99.13(66) \\
7.77(04) \\
0.23(04)\end{array}$ & $\begin{array}{c}56.54(40) \\
0.03(02) \\
13.65(89) \\
0.04(03) \\
2.94(30) \\
0.02(02) \\
16.93(123) \\
0.19(04) \\
6.78(47) \\
0.02(01) \\
2.24(01) \\
99.37(57) \\
7.57(03) \\
0.43(03)\end{array}$ & $\begin{array}{c}57.91(36) \\
0.01(01) \\
11.66(64) \\
\text { n.d. } \\
3.34(39) \\
\text { n.d. } \\
17.92(105) \\
0.19(04) \\
6.12(45) \\
0.02(01) \\
2.24(01) \\
99.42(63) \\
7.74(04) \\
0.26(04)\end{array}$ \\
\hline $\begin{array}{l}\mathrm{M}(123) \\
\mathrm{Al}^{(\mathrm{VI})} \\
\mathrm{Cr} \\
\mathrm{Ti} \\
\mathrm{Fe}^{2+} \\
\mathrm{Mg}^{2+}\end{array}$ & $\begin{aligned} & 1.78(11) \\
- & \\
- & \\
& 0.03(03) \\
& 3.18(15)\end{aligned}$ & $\begin{aligned} & 1.66(09) \\
- & \\
- & \\
& 0.14(09) \\
& 3.20(17)\end{aligned}$ & $\begin{array}{c}1.68(08) \\
- \\
0.01(00) \\
0.18(06) \\
3.12(13)\end{array}$ & $\begin{aligned} & 1.72(13) \\
- & \\
- & 0.01(01) \\
& 3.27(14)\end{aligned}$ & $\begin{aligned} & 1.74(09) \\
&- \\
&- \\
& 0.05(05) \\
& 3.20(15)\end{aligned}$ & $\begin{array}{l}1.67(10) \\
0.01(01) \\
0.02(02) \\
0.16(10) \\
3.15(18)\end{array}$ & $\begin{array}{l}1.72(14) \\
- \\
- \\
3.27(14)\end{array}$ & $\begin{array}{l}1.58(09) \\
- \\
- \\
0.01(01) \\
3.41(12)\end{array}$ \\
\hline $\begin{array}{l}\mathrm{M}(4) \\
\mathrm{Mg} \\
\mathrm{Fe}^{2+} \\
\mathrm{Mn} \\
\mathrm{Ca} \\
\mathrm{Na}\end{array}$ & $\begin{array}{r}0.04(04) \\
0.14(06) \\
-\quad \\
0.02(01) \\
1.80(09)\end{array}$ & $\begin{array}{r}- \\
- \\
- \\
- \\
0.38(09) \\
1.56(01)\end{array}$ & $\begin{array}{l}- \\
-0.30(06) \\
- \\
0.10(01) \\
1.59(05)\end{array}$ & $\begin{array}{r}0.20(15) \\
0.29(05) \\
- \\
0.02(01) \\
1.49(15)\end{array}$ & $\begin{array}{l}0.04(04) \\
0.37(08) \\
0.01(01) \\
0.04(01) \\
1.53(12)\end{array}$ & $\begin{array}{l}- \\
-0.31(10) \\
- \\
0.07(03) \\
1.39(54)\end{array}$ & $\begin{array}{c}0.11(11) \\
0.33(03) \\
- \\
0.03(01) \\
1.53(12)\end{array}$ & $\begin{array}{c}0.16(09) \\
0.36(05) \\
- \\
0.03(01) \\
1.45(10)\end{array}$ \\
\hline $\begin{array}{l}\text { A-site } \\
\mathrm{Na} \\
\mathrm{K} \\
\mathrm{OH} \\
\text { Altot. } \\
\text { Mgtot. }\end{array}$ & $\begin{array}{l}-0.17(06) \\
- \\
2.00 \\
1.95(11) \\
3.21(19)\end{array}$ & $\begin{array}{l}0.09(05) \\
0.01(00) \\
2.00 \\
1.86(10) \\
3.20(17)\end{array}$ & $\begin{array}{l}0.05(04) \\
- \\
2.00 \\
1.83(08) \\
3.12(13)\end{array}$ & $\begin{array}{l}-0.27(05) \\
- \\
2.00 \\
2.23(10) \\
3.47(28)\end{array}$ & $\begin{array}{l}0.17(07) \\
- \\
2.00 \\
2.09(11) \\
3.25(19)\end{array}$ & $\begin{array}{l}0.12(05) \\
- \\
2.00 \\
1.90(07) \\
3.16(19)\end{array}$ & $\begin{array}{l}0.23(07) \\
- \\
2.00 \\
2.15(14) \\
3.38(25)\end{array}$ & $\begin{array}{l}0.13(04) \\
- \\
2.00 \\
1.84(10) \\
3.57(20)\end{array}$ \\
\hline
\end{tabular}

${ }^{\mathrm{a}} \mathrm{Fe}_{\mathrm{tot}}=\mathrm{FeO}$

${ }^{b}$ Calculated

(Fig. 7B, F). Increasing temperature leads to an increase at 20 and $25 \mathrm{kbar}$, but at $30 \mathrm{kbar}$ no increase in total $\mathrm{Al}$ was observed in either set of experiments.

$M g$

The total Mg content shows no clear correlation with increasing pressure in any of the two series of experiments at 700,750 , and $800{ }^{\circ} \mathrm{C}$ (Fig. $\left.7 \mathrm{C}, \mathrm{G}\right)$ within uncertainty. The total $\mathrm{Mg}$ content increases with increasing temperature in both sets of experiments, except at $25 \mathrm{kbar}$ in the GJTQ experiments.

$N a$

The Na content on the A-site decreases with increasing pressure at 750 and $800{ }^{\circ} \mathrm{C}$ and decreases slightly in the experiments at $700{ }^{\circ} \mathrm{C}$ (Fig. 7D, H). Increasing temper- ature leads to an increase in the $\mathrm{Na}$ content on the A-site at 20 and 25 kbar (Fig. 7D, H). At 30 kbar almost no variation is indicated by the data and $\mathrm{Na}^{\mathrm{A}}$ stays constant in both sets of experiments.

\section{Minor elements}

Unlike the major elements, minor elements show no consistent changes with either pressure or temperature. All of the newly formed rim amphiboles have lower $\mathrm{Fe}^{2+}$ contents than the starting amphibole. However, given the extremely low $\mathrm{Fe}^{2+}$ of the talc, the observed $\mathrm{Fe}^{2+}$ contents of the amphiboles in most experiments are somewhat higher than expected. One experiment (run no. 9 with $\mathrm{Jd}+\mathrm{Tlc}+$ Gln seeds) yielded very low $\mathrm{Fe}^{2+}$ contents $(<0.05 \mathrm{apfu})$. This experiment shows that nearly pure glaucophane can be stable (cf. Pawley 1992). However, $\mathrm{Fe}^{2+}$ more typically ranges from 0.16 to 0.37 apfu $\quad\left(\mathrm{X}_{\mathrm{Fe}}=\left[\mathrm{Fe}^{2+} /\left(\mathrm{Fe}^{2+}+\mathrm{Mg}\right)\right]=0.05-0.10\right)$. 
Table 5 Average electron microprobe analyses of amphibole from the GJTQ experiments. Formulas normalized to $24(\mathrm{O}+\mathrm{OH})$. n.d: Not detected; numbers in parentheses are $1 \sigma$ standard deviation. Since the program MINFILE assigns $\mathrm{Mg}$ and $\mathrm{Al}$ to the $\mathrm{M}(123)$ sites, without considering the $\mathrm{Fe}^{2+} / \mathrm{Mg}$ ratio of the amphiboles, $\mathrm{Fe}^{2+}$ is mostly distributed to the M(4) site. Due to the small $\mathrm{Fe}^{2+}$ contents, no partitioning between the $\mathrm{M}(1,2,3)$ and $\mathrm{M}(4)$ sites, according to the $\mathrm{Fe}^{2+} / \mathrm{Mg}$ ratio, was calculated

\begin{tabular}{|c|c|c|c|c|c|c|c|c|}
\hline $\begin{array}{l}\mathrm{T}\left({ }^{\circ} \mathrm{C}\right) \\
\mathrm{P} \text { (kbar) } \\
\text { Run no. } \\
n\end{array}$ & $\begin{array}{c}700 \\
20 \\
8 \\
14\end{array}$ & $\begin{array}{r}700 \\
25 \\
16 \\
6\end{array}$ & $\begin{array}{r}700 \\
30 \\
179 \\
3\end{array}$ & $\begin{array}{l}750 \\
20 \\
86 \\
25\end{array}$ & $\begin{array}{l}750 \\
25 \\
93 \\
19\end{array}$ & $\begin{array}{r}750 \\
30 \\
97 \\
6\end{array}$ & $\begin{array}{l}800 \\
25 \\
94 \\
20\end{array}$ & $\begin{array}{l}800 \\
30 \\
98 \\
20\end{array}$ \\
\hline $\begin{array}{l}\mathrm{SiO}_{2} \\
\mathrm{TiO}_{2} \\
\mathrm{Al}_{2} \mathrm{O}_{3} \\
\mathrm{Cr}_{2} \mathrm{O}_{3} \\
\mathrm{FeO}^{\mathrm{a}} \\
\mathrm{MnO} \\
\mathrm{MgO} \\
\mathrm{CaO} \\
\mathrm{Na}_{2} \mathrm{O} \\
\mathrm{K}_{2} \mathrm{O} \\
\mathrm{H}_{2} \mathrm{O}^{\mathrm{b}} \\
\Sigma \\
\mathrm{Si} \\
\mathrm{Al}^{(\mathrm{IV})}\end{array}$ & $\begin{array}{r}58.72(83) \\
0.02(02) \\
12.77(54) \\
0.01(01) \\
1.74(28) \\
0.02(02) \\
16.44(70) \\
0.15(05) \\
7.53(33) \\
0.02(02) \\
2.27(02) \\
99.83(65) \\
7.79(06) \\
0.21(06)\end{array}$ & $\begin{array}{c}59.54(43) \\
0.04(03) \\
12.59(17) \\
\text { n.d. } \\
3.26(15) \\
0.03(01) \\
16.75(36) \\
0.26(04) \\
6.25(35) \\
0.03(01) \\
2.29(01) \\
101.5(56) \\
7.80(04) \\
0.20(04)\end{array}$ & $\begin{array}{r}59.80(49) \\
0.03(01) \\
12.00(43) \\
0.07(02) \\
2.18(27) \\
0.02(02) \\
15.20(57) \\
0.17(02) \\
7.27(45) \\
0.10(01) \\
2.25(02) \\
99.10(95) \\
7.96(01) \\
0.04(01)\end{array}$ & $\begin{array}{c}55.08(73) \\
0.03(03) \\
13.94(86) \\
0.03(03) \\
3.15(49) \\
0.03(02) \\
18.25(126) \\
0.21(07) \\
6.37(62) \\
0.03(03) \\
2.25(02) \\
99.36(65) \\
7.40(07) \\
0.60(07)\end{array}$ & $\begin{array}{r}56.53(73) \\
0.04(01) \\
13.33(44) \\
0.02(02) \\
3.43(52) \\
0.07(02) \\
16.80(59) \\
0.20(05) \\
6.63(44) \\
0.01(01) \\
2.23(02) \\
99.30(66) \\
7.59(06) \\
0.41(06)\end{array}$ & $\begin{array}{c}58.36(41) \\
0.03(02) \\
11.50(99) \\
0.01(02) \\
4.25(38) \\
0.04(02) \\
17.73(124) \\
0.42(10) \\
5.81(85) \\
0.04(02) \\
2.26(01) \\
100.46(73) \\
7.75(06) \\
0.25(06)\end{array}$ & $\begin{array}{c}56.09(71) \\
0.01(01) \\
13.72(45) \\
0.03(02) \\
3.81(51) \\
0.03(02) \\
17.04(104) \\
0.22(07) \\
6.49(40) \\
\text { n.d. } \\
2.24(02) \\
99.70(72) \\
7.51(07) \\
0.49(07)\end{array}$ & $\begin{array}{c}57.62(38) \\
0.03(03) \\
12.14(85) \\
0.02(02) \\
3.25(41) \\
0.04(03) \\
17.39(135) \\
0.28(06) \\
6.23(44) \\
0.02(01) \\
2.24(02) \\
99.26(72) \\
7.71(03) \\
0.29(03)\end{array}$ \\
\hline $\begin{array}{l}\mathrm{M}(123) \\
\mathrm{Al}^{(\mathrm{VI})} \\
\mathrm{Cr} \\
\mathrm{Ti} \\
\mathrm{Fe}^{2+} \\
\mathrm{Mg}\end{array}$ & $\begin{array}{l}1.78(06) \\
- \\
- \\
0.02(02) \\
3.20(08)\end{array}$ & $\begin{array}{r}1.75(03) \\
- \\
0.01(01) \\
0.01(01) \\
3.24(04)\end{array}$ & $\begin{aligned} & 1.85(08) \\
- & \\
- & \\
& 0.13(02) \\
& 3.02(10)\end{aligned}$ & $\begin{array}{l}1.61(14) \\
- \\
- \\
- \\
\\
3.39(13)\end{array}$ & $\begin{aligned} & 1.70(07) \\
- & \\
- & \\
- & 3.29(08)\end{aligned}$ & $\begin{aligned} & 1.55(13) \\
- & \\
- & \\
& 0.03(03) \\
& 3.42(18)\end{aligned}$ & $\begin{array}{l}1.68(10) \\
- \\
- \\
0.01(01) \\
3.30(11)\end{array}$ & $\begin{array}{l}1.63(14) \\
- \\
- \\
0.01(01) \\
3.36(15)\end{array}$ \\
\hline $\begin{array}{l}\mathrm{M}(4) \\
\mathrm{Mg} \\
\mathrm{Fe}^{2+} \\
\mathrm{Mn} \\
\mathrm{Ca} \\
\mathrm{Na}\end{array}$ & $\begin{array}{r}0.06(06) \\
0.16(05) \\
- \\
0.02(01) \\
1.76(07)\end{array}$ & $\begin{array}{r}0.03(03) \\
0.35(01) \\
-\quad \\
0.04(01) \\
1.55(06)\end{array}$ & $\begin{array}{r}- \\
-\quad 0.11(01) \\
0.02(00) \\
1.83(06)\end{array}$ & $\begin{array}{c}0.27(13) \\
0.35(06) \\
- \\
0.03(01) \\
1.34(15)\end{array}$ & $\begin{array}{l}0.07(06) \\
0.38(06) \\
0.01(00) \\
0.03(01) \\
1.51(10)\end{array}$ & $\begin{array}{r}0.09(09) \\
0.45(09) \\
- \\
0.06(02) \\
1.39(17)\end{array}$ & $\begin{array}{c}0.10(10) \\
0.42(05) \\
- \\
0.03(01) \\
1.45(12)\end{array}$ & $\begin{array}{c}0.12(11) \\
0.35(04) \\
- \\
0.04(01) \\
1.49(13)\end{array}$ \\
\hline $\begin{array}{l}\text { A-site } \\
\mathrm{Na} \\
\mathrm{K} \\
\mathrm{OH} \\
\text { Altot. } \\
\text { Mgtot. }\end{array}$ & $\begin{array}{l}0.18(05) \\
- \\
2.00 \\
1.99(09) \\
3.26(13)\end{array}$ & $\begin{array}{l}0.04(03) \\
-\quad \\
2.00 \\
1.95(02) \\
3.27(07)\end{array}$ & $\begin{array}{l}0.05(06) \\
0.02(00) \\
2.00 \\
1.89(08) \\
3.02(10)\end{array}$ & $\begin{array}{l}0.32(06) \\
0.01(01) \\
2.00 \\
2.21(13) \\
3.65(26)\end{array}$ & $\begin{array}{l}0.21(04) \\
- \\
2.00 \\
2.11(07) \\
3.36(12)\end{array}$ & $\begin{array}{l}0.11(06) \\
0.01(01) \\
2.00 \\
1.80(16) \\
3.51(25)\end{array}$ & $\begin{array}{l}0.24(06) \\
- \\
2.00 \\
2.17(07) \\
3.40(20)\end{array}$ & $\begin{array}{l}0.13(04) \\
- \\
2.00 \\
1.91(14) \\
3.47(26)\end{array}$ \\
\hline
\end{tabular}

${ }^{\mathrm{a}} \mathrm{Fe}_{\mathrm{tot}}=\mathrm{FeO}$

${ }^{b}$ Calculated

Where amphibole neoblasts form very thin rims $(<3 \mu \mathrm{m})$, higher $\mathrm{Fe}^{2+}$ contents $\left(0.37-0.49\right.$ apfu; $\mathrm{X}_{\mathrm{Fe}}=$ $0.10-0.14)$ are common. This affects mostly the GJT and GJTQ experiments at $700{ }^{\circ} \mathrm{C}(25$ and $30 \mathrm{kbar})$ and at $750{ }^{\circ} \mathrm{C}$ (30 kbar). In one experiment (run no. 98 at $800^{\circ} \mathrm{C}, 30 \mathrm{kbar}$ ) where amphibole neoblasts form rims wide enough to perform reliable probe analysis, the high $\mathrm{Fe}^{2+}$ content is probably caused by contamination of the starting assemblage by allanite or chlorite inclusions in glaucophane. In addition, as illustrated by Fig. 3, textures of amphibole neoblasts may suggest that some of the newly formed amphibole replaced the glaucophane seeds in the starting assemblage, which could lead to a diffusive uptake of $\mathrm{Fe}^{2+}$ from the starting amphibole and might also explain higher $\mathrm{Fe}^{2+}$ contents.

The $\mathrm{Ca}$ and $\mathrm{Ti}$ contents in the newly grown amphiboles are low (0.02-0.06 and 0.01-0.02 apfu, respectively). One experiment (run no. 52) at $700{ }^{\circ} \mathrm{C}$ and $30 \mathrm{kbar}$ shows elevated $\mathrm{Ca}$ contents $(0.06-0.11 \mathrm{apfu})$, which is probably caused by contamination by allanite inclusions or glaucophane of the starting assemblage. The $\mathrm{Cr}$ and $\mathrm{Mn}$ contents are always very low $(<0.01 \mathrm{apfu})$.

Variation of coupled substitutions with pressure and temperature

The major changes in the composition of sodic amphiboles in the experiments occurs on the tetrahedral, octahedral, and A-sites. Amphibole compositions were therefore plotted in $\mathrm{Al}^{\mathrm{IV}}-\mathrm{Al}^{\mathrm{VI}}$ and $\mathrm{Al}^{\mathrm{IV}}-\mathrm{Na}^{\mathrm{A}}$ diagrams. Examples from the GJT experiments are shown in Fig. 8A-D. The $\mathrm{Al}^{\mathrm{IV}}, \mathrm{Al}^{\mathrm{VI}}$, and $\mathrm{Na}^{\mathrm{A}}$ values, and the $1 \sigma$ uncertainties of both sets of experiments (GJT, GJTQ) are given in Tables 4 and 5 .

Increasing temperature at constant pressure of $20 \mathrm{kbar}$ leads to an increase in $\mathrm{Al}^{\mathrm{IV}}$ and therefore a substitution towards nyböite and $\mathrm{Al}-\mathrm{Na}$-cummingtonite in the $\mathrm{Al}^{\mathrm{IV}}-\mathrm{Al}^{\mathrm{VI}}$ diagram (Fig. $8 \mathrm{~A}$ ). An $\mathrm{Al}^{\mathrm{IV}}-\mathrm{Na}^{\mathrm{A}}$ plot at $20 \mathrm{kbar}$ also shows a clear increase in A-site occu- 

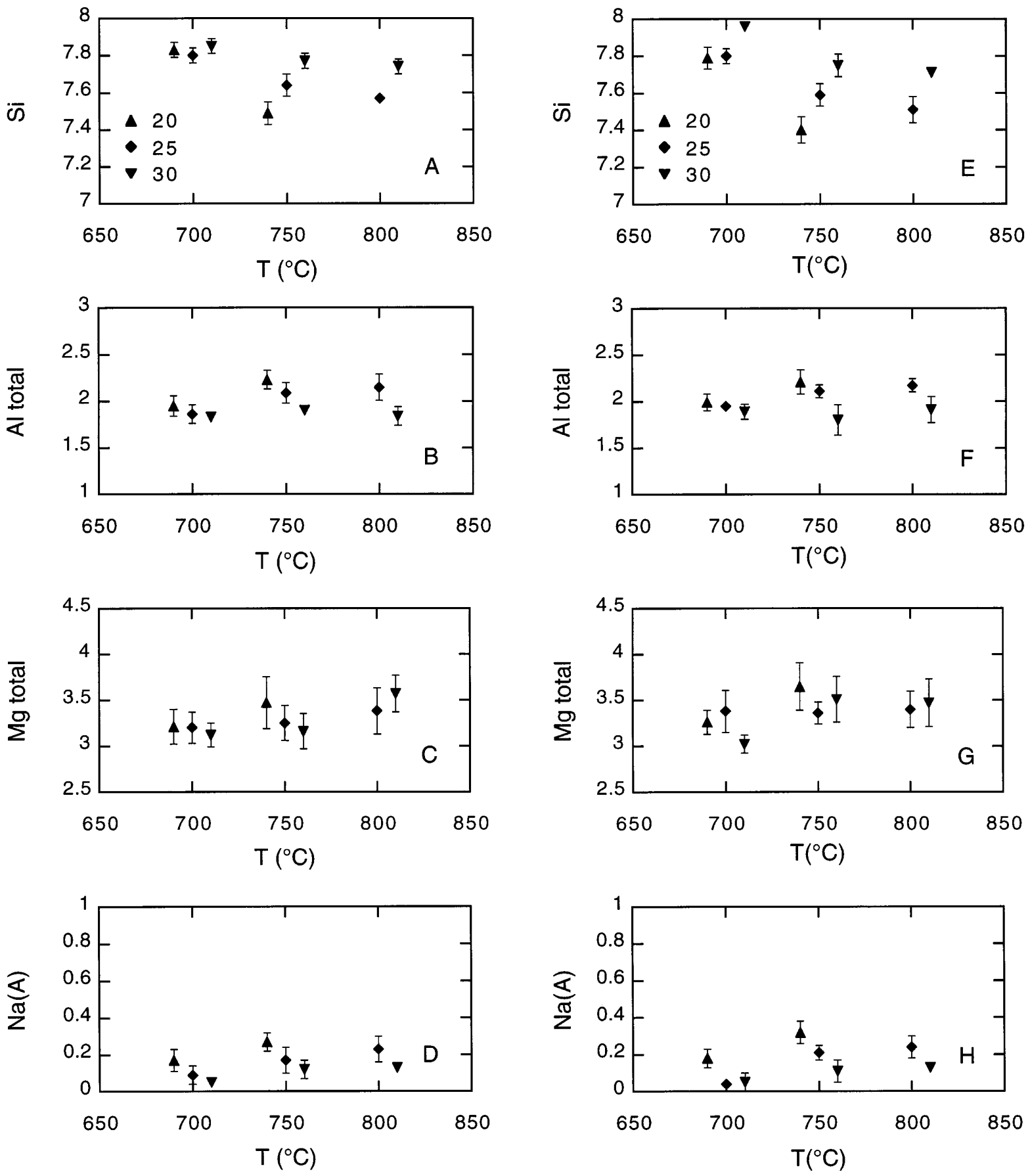

Fig. 7 A-H Chemical variation in amphibole composition as a function of changing pressures and temperatures. A-D: results from the glaucophane-jadeite-talc (GJT) experiments; $\mathbf{E}-\mathbf{H}$ : results from the glaucophane-jadeite-talc-quartz (GJTQ) experiments. The data are shown with increasing temperature from 700 to $800{ }^{\circ} \mathrm{C}$ and pressures, of $20 \mathrm{kbar}$ (black triangles), $25 \mathrm{kbar}$ (black diamonds), and $30 \mathrm{kbar}$ (black upside-down triangles). At each temperature, the results of experiments at different pressures are plotted next to each other for comparison. A-D: GJT experiments: A Si content; B total Al content; C total $\mathrm{Mg}$ content; D $\mathrm{Na}$ content on the A-site; E-H: GJTQ experiments: $\mathbf{E}$ Si content; $\mathbf{F}$ total $\mathrm{Al}$ content; $\mathbf{G}$ total $\mathrm{Mg}$ content; H Na content on the A-site. The error bars are one standard deviation $(1 \sigma)$ and are omitted if $1 \sigma$ is smaller than the symbol

pancy with increasing temperature from 700 to $750{ }^{\circ} \mathrm{C}$ (Fig. 8B). The data at $700{ }^{\circ} \mathrm{C}$ are on the ideal trend line towards nyböite, whereas the data at $750{ }^{\circ} \mathrm{C}$ are displaced from this line towards higher $\mathrm{Al}^{\mathrm{IV}}$ values.

Increasing pressure at $750{ }^{\circ} \mathrm{C}$ in the GJT runs produced a trend from nyböitic amphiboles towards glaucophanes in the $\mathrm{Al}^{\mathrm{VI}-} \mathrm{Al}^{\mathrm{IV}}$ diagram (Fig. 8C). The glaucophane-rich compositions at $30 \mathrm{kbar}$ in Fig. $8 \mathrm{C}$ are slightly displaced towards cummingtonite, although the variation in total $\mathrm{Mg}$ with pressure in Fig. $7 \mathrm{C}, \mathrm{G}$ do not indicate a systematic trend towards cummingtonite with increasing pressure. Increase in pressure at $750{ }^{\circ} \mathrm{C}$ also leads to a decrease in $\mathrm{Na}^{\mathrm{A}}$ from 20 to $30 \mathrm{kbar}$, although 


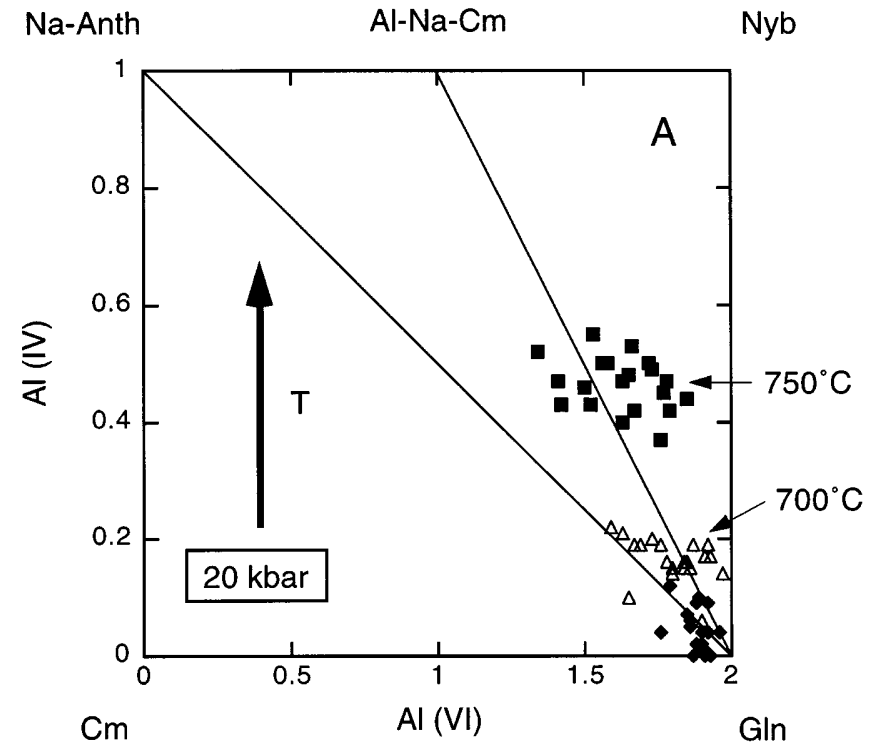

Nyb

Na-Anth

Al-Na-Cm

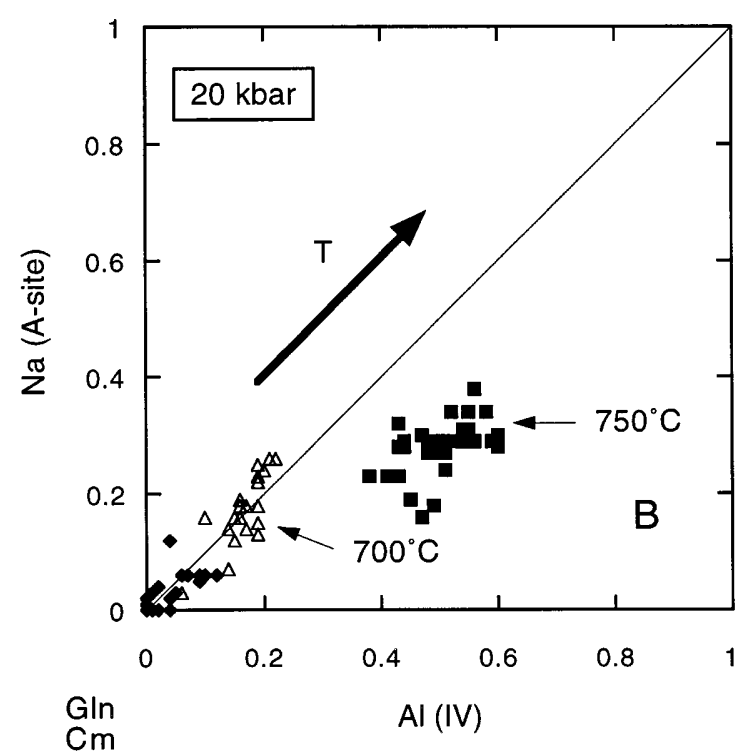

Fig. 8 A-D Compositional variation of synthetic amphiboles from GJT experiments of this study. A $\mathrm{Al}^{\mathrm{IV}}-\mathrm{Al}^{\mathrm{IV}}$ plot of the data at $20 \mathrm{kbar}$ and temperatures of $700{ }^{\circ} \mathrm{C}$ (open triangles; run no. 3) and $750{ }^{\circ} \mathrm{C}$ (filled boxes; run no. 90). $\mathrm{B} \mathrm{Na}^{\mathrm{A}}-\mathrm{Al}^{\mathrm{IV}}$ plot of the data from the same experiments. $\mathrm{C} \mathrm{Al}^{\mathrm{IV}}-\mathrm{Al}^{\mathrm{IV}}$ plot at $750{ }^{\circ} \mathrm{C}$ and pressures of 20 kbar (open circles; run no. 90), 25 kbar (filled boxes; run no. 95) and 30 kbar (open triangles; run no. 55). $\mathbf{D ~ N a}{ }^{\mathrm{A}}-\mathrm{Al}^{\mathrm{IV}}$ plot of the data from the same experiments. The black diamonds in all diagrams represent the compositions of the starting amphiboles. The $1 \sigma$ standard deviations have been omitted in these diagrams for clarity and can be found in Tables 4 and 5

the data are slightly displaced from the ideal trend towards nyböite by showing slightly higher $\mathrm{Al}^{\mathrm{IV}}$ values (Fig. 8D). The observed substitutions indicate that the substitution towards nyböite and Al-Na-cummingtonite is dominant with decreasing pressures and increasing temperatures. These substitutions are clearly visible in
Na-Anth $\quad$ Al-Na-Cm Nyb

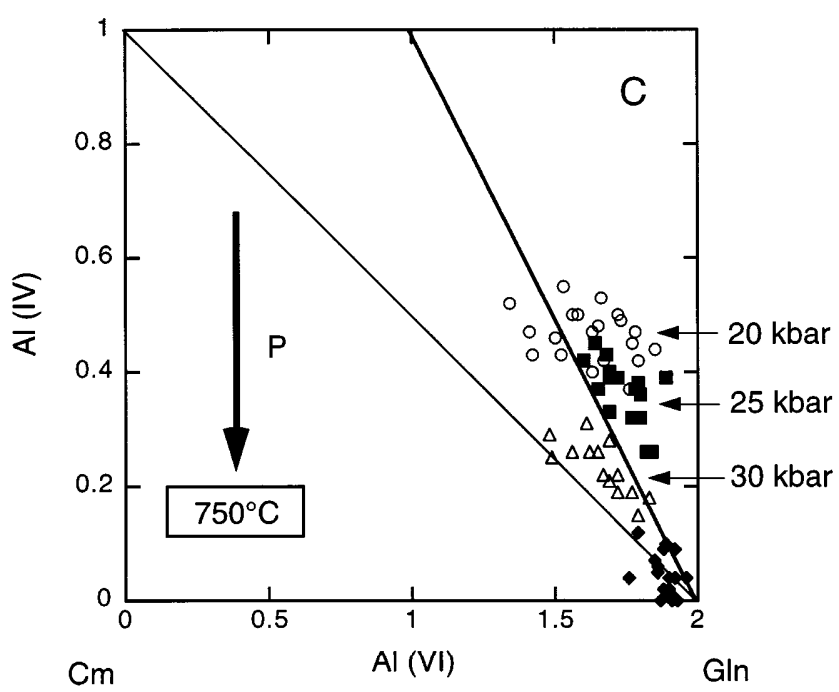

Nyb

Na-Anth

$\mathrm{Al}-\mathrm{Na}-\mathrm{Cm}$

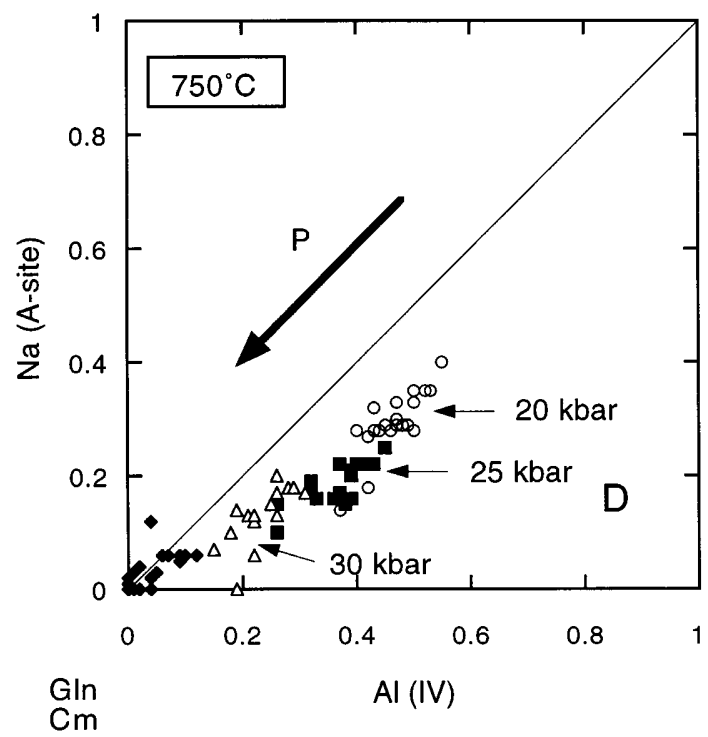

all GJT and GJTQ experiments and support the results of earlier experimental investigations by Carman and Gilbert (1983), Pawley (1992) and Welch and Graham (1992).

Overall, the data indicate that (1) the variation in the elements $(\mathrm{Mg}, \mathrm{Al})$ on the octahedral sites $\mathrm{M}(1,2,3)$ is greater than on the tetrahedral sites and A-site as seen in Fig. 7, and (2) the $\mathrm{Si}$ content (and $\mathrm{Al}^{\mathrm{IV}}$ content) and $\mathrm{Na}^{\mathrm{A}}$ appear to be sensitive monitors of changes in pressure and temperature.

Although not plotted in Fig. 8, GJTQ experiments show only slight differences in substantial trends with varying pressure and temperature when compared to the GJT runs. The $\mathrm{Al}^{\mathrm{IV}}$ content in the GJT experiments at high temperatures $\left(>750{ }^{\circ} \mathrm{C}\right)$ is somewhat lower than in the GJTQ experiments, and the scatter 
in $\mathrm{Al}^{\mathrm{IV}}$ in both sets of experiments is less than in $\mathrm{Al}^{\mathrm{VI}}$. This might be caused by a small degree of melting in the GJTQ experiments, since quartz is present and most experiments span the conditions where the reactions

Jadeite + Quartz $/$ Coesite $+\mathrm{H}_{2} \mathrm{O}=$ Melt

Jadeite $+\mathrm{H}_{2} \mathrm{O}=$ Melt

take place (Boettcher and Wyllie 1969). The source of $\mathrm{H}_{2} \mathrm{O}$ for melting could have been reactions involving sodium anthophyllite and $\mathrm{Al}-\mathrm{Na}$-cummingtonite, since both reactions release $\mathrm{H}_{2} \mathrm{O}$. If melting occurred, it must not have been extensive, since no evidence of melting was found by examining the samples with XRD and SEM.

\section{Discussion}

Complex solid solutions in the synthetic amphiboles are not unexpected, since jadeite and talc in the starting assemblage buffer simultanously the amphibole species glaucophane, cummingtonite, nyböite, sodium anthophyllite and Al-Na-cummingtonite by reaction (1) as well as the following reactions:

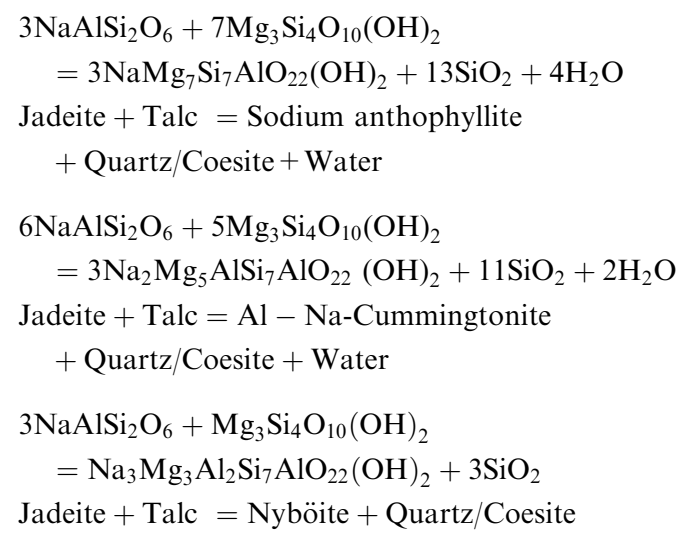

All reactions except (1) produce quartz or coesite; reactions (4) and (5) also release $\mathrm{H}_{2} \mathrm{O}$, which might cause a small degree of melting, or the formation of metastable Na-phyllosilicates in the experiments.

Many of the experiments at 750 and $800{ }^{\circ} \mathrm{C}$ lack talc in the final assemblage. The extent of $\mathrm{Mg}$ substitution in our experiments is also higher than expected, perturbing the preferred distribution of $\mathrm{Na}$ on the $\mathrm{M}(4)$ site as would be expected with increasing pressure (Laird 1982). The instability of talc in some of the 750 and $800{ }^{\circ} \mathrm{C}$ runs is explained by (1) progress of the reaction

$2 \mathrm{Mg}_{3} \mathrm{Si}_{4} \mathrm{O}_{10}(\mathrm{OH})_{2}=3 \mathrm{Mg}_{2} \mathrm{Si}_{2} \mathrm{O}_{6}+2 \mathrm{SiO}_{2}+2 \mathrm{H}_{2} \mathrm{O}$

Talc $=$ Enstatite + Quartz $/$ Coesite + Water

or (2) by increasing consumption of talc through the reaction

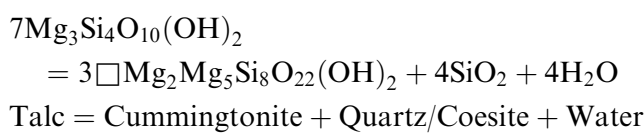

The occurrence of small enstatite crystals and quartz in some experiments at these temperatures (Table 3) suggests that reaction (7) is initiated. Calculation of reaction (7) with THERMOCALC v. 2.5 shows that talc breaks down at ca. $815^{\circ} \mathrm{C}$ between 20 and $30 \mathrm{kbar}$. Reaction (8) calculated with pure end members would be well outside the temperature range of our investigation, but the activity of $\square \mathrm{Mg}_{2} \mathrm{Mg}_{5} \mathrm{Si}_{8} \mathrm{O}_{22}(\mathrm{OH})_{2}$ is dramatically reduced in the newly grown amphiboles $(<0.02$ based on an ideal ionic activity model) and shifts the curve down to lower temperatures.

Comparison to natural amphiboles from UHP terranes

Chopin (1986) and Schertl et al. (1991) reported Naamphibole inclusions in pyrope crystals from the Dora Maira Massif in northern Italy. They are considered to be part of the assemblage pyrope-kyanite-ellenbergerite- $\mathrm{Mg}$-chlorite, which probably formed at 30-35 kbar and $700-800{ }^{\circ} \mathrm{C}$. Later retrogression led to the formation of glaucophane along cracks and grain boundaries in garnet-jadeite-quartzite layers (Schertl et al. 1991). The composition of the inclusions deviates considerably from glaucophane with excess $\mathrm{Mg}$ on the octahedral site (Table 6) and $\mathrm{Al}^{\mathrm{IV}}$ substitution for Si (Fig. 9A), but almost no substitution on the A-site (Fig. 9B), whereas glaucophane formed during retrogression is very close to its end member composition. In an $\mathrm{Al}^{\mathrm{VI}}-\mathrm{Al}^{\mathrm{IV}}$ plot the Na-amphiboles plot very close to our data from the GJTQ experiments at $750{ }^{\circ} \mathrm{C}$ and 20 to $30 \mathrm{kbar}$, whereas in an $\mathrm{Al}^{\mathrm{IV}}-\mathrm{Na}^{\mathrm{A}}$ plot the data overlap only with the 30 kbar data since these amphiboles have almost no $\mathrm{Na}$ on the A-site.

Zhang and Liou (1994) described "glaucophanic" amphiboles from coesite-bearing eclogites from the Henan Province, central China. In contrast to Dora Maira, glaucophane occurs in the matrix that is part of the peak assemblage garnet-coesite-kyanite-omphacitephengite-talc, which is stable at $31 \mathrm{kbar}$ and $620 \pm$ $30{ }^{\circ} \mathrm{C}$. These amphiboles show significant $\mathrm{Al}^{\mathrm{IV}}$ substitution for $\mathrm{Si}$, less $\mathrm{Al}^{\mathrm{VI}}$ on the octahedral site, and increased A site occupancy (Fig. 9B, Table 6). Since the temperature of formation is much lower than in our experiments, a comparison of these data with our experimental results is not very reliable

In contrast to the previously mentioned localities, the Sesia-Lanzo Zone did not experience such high pressures and temperatures. Peak conditions are estimated to be between 15 and $21 \mathrm{kbar}$ at ca. $500-600{ }^{\circ} \mathrm{C}$ (Venturini 1995; Tropper 1998). The sodic amphibole described from this area is nearly end member glaucophane (Fig. 9A, B). 
Table 6 Published amphibole analyses from high pressure terranes. Formulas normalized to $24(\mathrm{O}+\mathrm{OH})$. n.d. Not detected; $(1$, $2,3)$ amphiboles from Henan Province, China, $(1,3)$ analyses from Zhang and Liou (1994), (2) Okay (1993); (4, 5, 6) amphibole inclusions in pyrope from Dora Maira, Italy; $(4,5)$ analyses from
(Schertl et al. 1991); (6) analysis from Chopin (1986); (7) secondary glaucophane from Schertl et al. (1991); (8) nyböite from Nybö, Norway, Ungaretti et al. (1981); $(9,10)$ nyböite analyses from Donghai Mts., China, Hirajima et al. (1992); (11, 12) nyböite analyses from Dora Maira, Italy (Hirajima and Compagnoni 1993)

\begin{tabular}{|c|c|c|c|c|c|c|c|c|c|c|c|c|}
\hline & 1 & 2 & 3 & 4 & 5 & 6 & 7 & 8 & 9 & 10 & 11 & 12 \\
\hline $\mathrm{SiO}_{2}$ & 55.48 & 55.38 & 57.01 & 57.80 & 58.38 & 58.28 & 59.19 & 53.84 & 50.89 & 48.87 & 46.91 & 48.86 \\
\hline $\mathrm{TiO}_{2}$ & 0.09 & 0.05 & 0.01 & 0.06 & 0.01 & 0.08 & 0.01 & 0.16 & 0.08 & n.d. & 0.40 & 0.39 \\
\hline $\mathrm{Al}_{2} \mathrm{O}_{3}$ & 11.13 & 9.54 & 10.81 & 13.91 & 13.07 & 14.37 & 11.94 & 12.92 & 12.09 & 12.92 & 12.86 & 11.18 \\
\hline $\mathrm{Cr}_{2} \mathrm{O}_{3}$ & 1.31 & 0.06 & n.d. & n.d. & n.d. & n.d. & n.d. & n.d. & n.d. & n.d. & n.d. & n.d. \\
\hline $\mathrm{FeO}^{\mathrm{a}}$ & 6.60 & 8.55 & 6.76 & 0.89 & 1.03 & 0.75 & 3.75 & 5.03 & 9.76 & 10.64 & 20.06 & 17.28 \\
\hline $\mathrm{MnO}$ & 0.02 & 0.05 & n.d. & 0.05 & n.d. & 0.03 & n.d. & 0.02 & 0.07 & n.d. & n.d. & n.d. \\
\hline $\mathrm{MgO}$ & 13.29 & 13.77 & 13.92 & 17.32 & 18.56 & 16.26 & 13.79 & 14.21 & 12.42 & 12.38 & 5.61 & 7.47 \\
\hline $\mathrm{CaO}$ & 1.81 & 2.67 & 2.43 & 0.60 & 0.99 & 0.75 & 0.18 & 2.33 & 2.93 & 3.71 & 3.60 & 2.93 \\
\hline $\mathrm{Na}_{2} \mathrm{O}$ & 7.25 & 6.21 & 7.10 & 5.89 & 4.91 & 5.60 & 6.89 & 9.26 & 8.42 & 8.32 & 7.85 & 7.95 \\
\hline $\mathrm{K}_{2} \mathrm{O}$ & 0.11 & 0.02 & n.d. & 0.07 & 0.12 & 0.12 & 0.09 & 0.14 & 0.27 & 0.29 & 0.50 & 0.37 \\
\hline $\mathrm{H}_{2} \mathrm{O}^{\mathrm{b}}$ & 2.17 & 2.14 & 2.20 & 2.26 & 2.27 & 2.26 & 2.23 & 2.19 & 2.11 & 2.09 & 2.01 & 2.02 \\
\hline$\Sigma$ & 99.26 & 98.44 & 100.24 & 98.85 & 99.34 & 98.50 & 98.06 & 100.10 & 99.04 & 99.22 & 99.80 & 98.45 \\
\hline $\mathrm{Si}$ & 7.65 & 7.75 & 7.76 & 7.67 & 7.70 & 7.74 & 8.00 & 7.38 & 7.25 & 7.02 & 7.26 & 7.00 \\
\hline $\mathrm{Al}^{(\mathrm{IV})}$ & 0.35 & 0.25 & 0.24 & 0.33 & 0.30 & 0.26 & n.d. & 0.62 & 0.75 & 0.98 & 0.74 & 1.00 \\
\hline \multicolumn{13}{|l|}{ M(123) } \\
\hline $\mathrm{Al}^{(\mathrm{VI})}$ & 1.46 & 1.32 & 1.49 & 1.85 & 1.74 & 1.98 & 1.90 & 1.47 & 1.28 & 1.20 & 1.22 & 1.26 \\
\hline $\mathrm{Cr}$ & 0.14 & 0.01 & n.d. & n.d. & n.d. & n.d. & n.d. & n.d. & n.d. & n.d. & n.d. & n.d. \\
\hline $\mathrm{Ti}$ & 0.01 & 0.01 & $<0.01$ & 0.01 & $<0.01$ & 0.01 & $<0.01$ & 0.02 & 0.01 & n.d. & 0.04 & 0.04 \\
\hline $\mathrm{Fe}^{2+}$ & 0.65 & 0.79 & 0.68 & n.d. & n.d. & n.d. & 0.32 & 0.58 & 1.08 & 1.14 & 2.08 & 2.44 \\
\hline $\mathrm{Mn}$ & n.d. & n.d. & n.d. & n.d. & n.d. & n.d. & n.d. & $<0.01$ & n.d. & n.d. & n.d. & n.d. \\
\hline $\mathrm{Mg}$ & 2.73 & 2.87 & 2.82 & 3.15 & 3.26 & 3.01 & 2.78 & 2.90 & 2.64 & 2.65 & 1.66 & n.d. \\
\hline \multicolumn{13}{|l|}{$\mathrm{M}(4)$} \\
\hline $\mathrm{Mg}$ & n.d. & n.d. & n.d. & 0.28 & 0.39 & 0.21 & n.d. & n.d. & n.d. & n.d. & n.d. & n.d. \\
\hline $\mathrm{Fe}^{2+}$ & 0.11 & 0.21 & 0.08 & 0.10 & 0.11 & 0.08 & 0.11 & n.d. & 0.09 & 0.13 & 0.07 & 0.06 \\
\hline $\mathrm{Mn}$ & n.d. & 0.01 & n.d. & 0.01 & n.d. & $<0.01$ & n.d. & n.d. & 0.01 & n.d. & n.d. & n.d. \\
\hline $\mathrm{Ca}$ & 0.27 & 0.40 & 0.35 & 0.09 & 0.14 & 0.11 & 0.03 & 0.34 & 0.45 & 0.57 & 0.47 & 0.58 \\
\hline $\mathrm{Na}$ & 1.62 & 1.39 & 1.56 & 1.52 & 1.26 & 1.44 & 1.81 & 1.66 & 1.46 & 1.30 & 1.47 & 1.36 \\
\hline \multicolumn{13}{|l|}{ A-site } \\
\hline $\mathrm{Na}$ & 0.32 & 0.30 & 0.31 & n.d. & n.d. & n.d. & n.d. & 0.80 & 0.87 & 1.02 & 0.83 & 0.91 \\
\hline K & 0.02 & $<0.01$ & n.d. & 0.01 & 0.02 & 0.02 & 0.02 & 0.02 & 0.05 & 0.05 & 0.07 & 0.10 \\
\hline $\mathrm{OH}$ & 2.00 & 2.00 & 2.00 & 2.00 & 2.00 & 2.00 & 2.00 & 2.00 & 2.00 & 2.00 & 2.00 & 2.00 \\
\hline
\end{tabular}

${ }^{\mathrm{a}} \mathrm{Fe}_{\mathrm{tot}}=\mathrm{FeO}$

${ }^{\mathrm{b}}$ Calculated

Another sodic amphibole, nyböite, has also been found in rocks from some UHP terranes. Nyböite has been described from the Nybö pod in Norway (Ungaretti et al. 1981), the Donghai area in China (Hirajima et al. 1992), and the Dora Maira Massif (Hirajima and Compagnoni 1993). Nyböites from China are thought to have formed under high pressure (20-28 kbar) and temperature $\left(700-800{ }^{\circ} \mathrm{C}\right)$ conditions, whereas those from Dora Maira formed under somewhat lower pressures and temperatures $\left(12-15 \mathrm{kbar}, 500-570{ }^{\circ} \mathrm{C}\right)$. In an $\mathrm{Al}^{\mathrm{IV}}-\mathrm{Al}{ }^{\mathrm{VI}}$ plot, the compositions of the nyböites actually plot close to the hypothetical $\mathrm{Al}-\mathrm{Na}$-cummingtonite end member due to a decrease in $\mathrm{Al}^{\mathrm{VI}}$ (Fig. 9A) and the full occupancy of the A-site by $\mathrm{Na}$ (Fig. 9B). Natural nyböites agree with the data of Pawley (1992), since her experiments started out on a nyböite bulk composition. The synthetic amphiboles from our experiments show a compositional trend toward nyböite and Al-Na-cummingtonite, but even runs at $800{ }^{\circ} \mathrm{C}$ did not yield such high nyböite contents as reported in the literature. This implies that formation of nearly pure nyböite likely requires different bulk composition than existed in our experiments (i.e., nearly pure glaucophane).

\section{Thermobarometric applications}

The Al content of calcic amphiboles has been recognized as an important parameter for using amphibole compositions as a pressure or temperature indicator. This observation is based on the empirical correlation between amphibole composition and metamorphic grade (Laird and Albee 1981) and on experimental investigations on calcic amphiboles (Maruyama et al. 1986; Johnson and Rutherford 1989; Jenkins 1994; Sharma 1996; Ernst and Liu 1998). Since all previous experimental investigations deal with the compositional change of calcic amphiboles from tremolite towards hornblende compositions, or the substitution of a sodic amphibole component (glaucophane) in calcic amphiboles, our data represent the first systematic experimental investigation on the behavior of sodic amphibole 
composition at high pressures and temperatures. The data show that the $\mathrm{Si}$ content (and hence $\mathrm{Al}^{\mathrm{IV}}$ content) of the newly formed amphiboles seems to monitor changes in pressure and temperature very well.
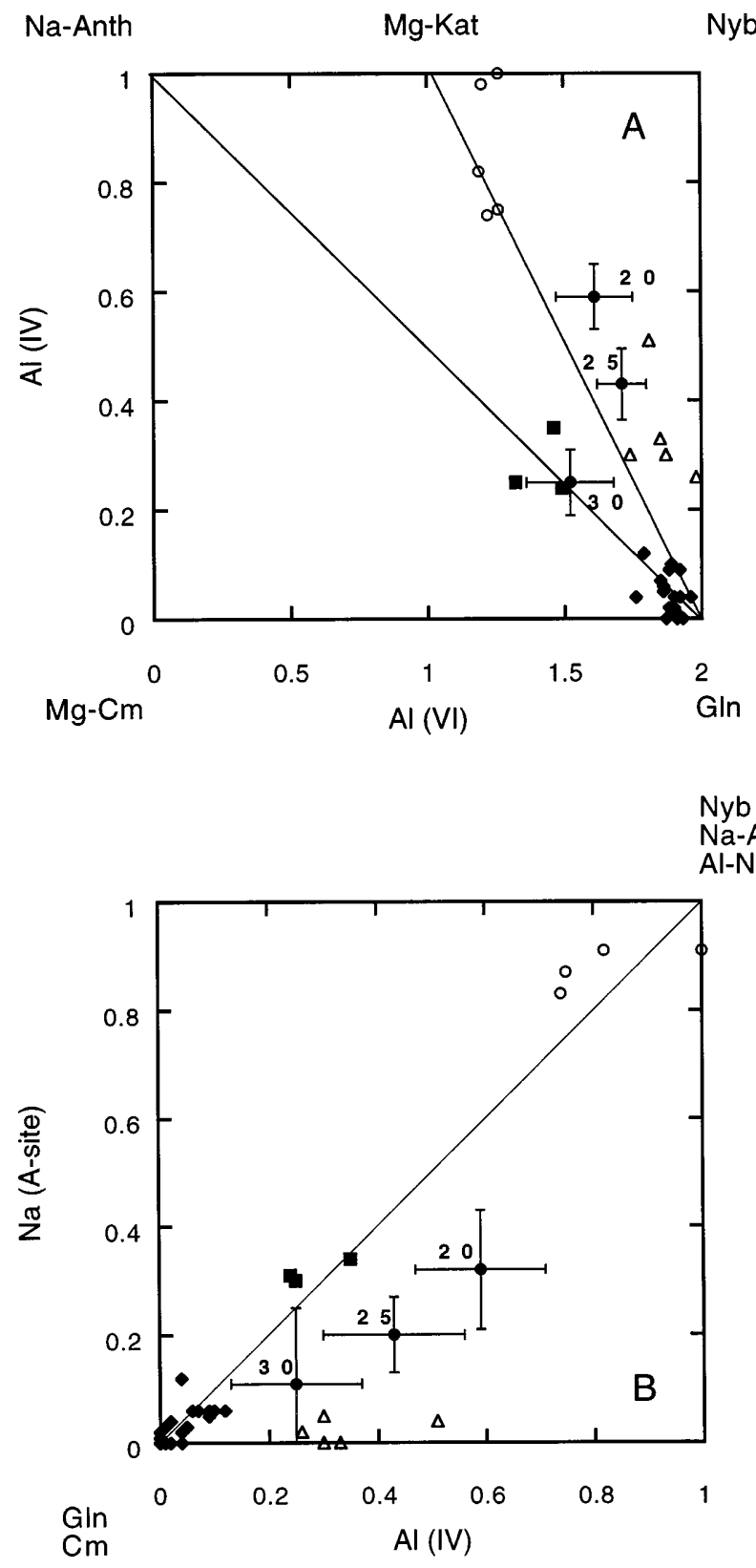

Fig. 9 A,B Compositional variation of natural "glaucophanes" from high (HP; <20 kbar) and ultra-high pressure (UHP; > $20 \mathrm{kbar}$ ) terranes. Glaucophanes from HP eclogites from the Sesia-Lanzo Zone, Western Alps, Italy (black diamonds); glaucophane inclusions in pyrope crystals from the UHP whiteschists from the Dora Maira Massif, Westem Alps, Italy (open triangles), and glaucophanes from the UHP jadeite gneisses from the Henan Province, China (black squares). The nyböites (open circles) are from UHP rocks from the Donghai Area (China), Dora Maira (Westem Alps, Italy), and the Western Gneiss Region (Norway). A Al ${ }^{\mathrm{IV}}-\mathrm{Al}^{\mathrm{VI}}$ plot. Some of the experimental data from this study are shown for comparison. The filled circles and $l \sigma$ standard deviation show the distribution of the data of the GJTQ experiments at $750{ }^{\circ} \mathrm{C}$ and 20,25 , and $30 \mathrm{kbar}$. $\mathbf{B ~ N a}{ }^{\mathrm{A}}-\mathrm{Al}^{\mathrm{IV}}$ plot; the data and labels are the same as in $\mathbf{A}$
Figure 10 shows empirically fit contours of $\mathrm{Al}^{\mathrm{IV}}$ isopleths over the investigated pressure-temperature space. The isopleths in both sets of experiments, GJT and GJTQ, are very steep at lower temperatures $\left(<750{ }^{\circ} \mathrm{C}\right)$ and curve towards shallow slopes at temperatures between 750 and $800{ }^{\circ} \mathrm{C}$. These isopleths represent a possible thermobarometer in the NMASH system at high pressures and temperatures. The use of them as a thermobarometer is probably hampered by the fact that the
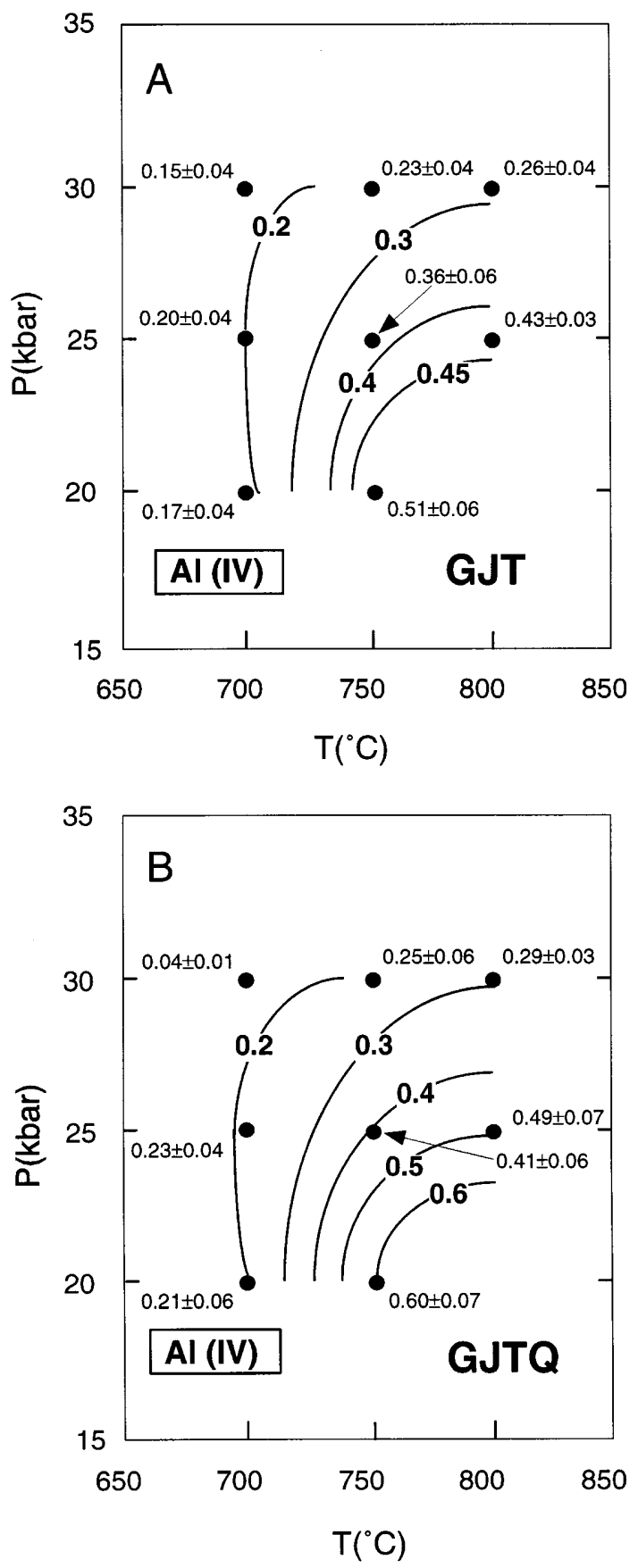

Fig. 10 Contoured isopleths of $\mathrm{Al}^{\mathrm{IV}}$ from GJT A and GJTQ B experiments. The black circles indicate the pressure-temperature conditions of the experiments and the values of $\mathrm{Al}^{\mathrm{IV}}$ with $1 \sigma$ standard deviations 
slope of the isopleths is strongly dependent on the associated mineral assemblage. The change in the slope of isopleths has not been investigated in the NMASH system so far, but experiments in other systems such as the NCMASH system (Sharma 1996) and the CMASH system (Jenkins 1994) clearly show the influence of the buffering assemblage on the slope of the isopleths. The pressure and temperature conditions of geologic environments containing sodic amphiboles represents another problem. Most sodic amphiboles occur at lower pressure $(<15 \mathrm{kbar})$ and temperature $\left(<600^{\circ} \mathrm{C}\right)$, which also leads to different solid solutions (e.g. crossite/riebeckite) than in our experiments. Therefore the isopleths in Fig. 10 are more important in terms of illustrating compositional trends associated with changes in pressure and temperature. The restricted observation of natural amphiboles from UHP terranes, especially from Dora Maira, allows a direct comparison, since their temperature of formation is similar to our experiments $\left(700-800{ }^{\circ} \mathrm{C},>20 \mathrm{kbar}\right)$. The glaucophane inclusions in pyrope contain $0.34(0.1)$ apfu $\mathrm{Al}^{\mathrm{IV}}$, which yields a pressure at $750{ }^{\circ} \mathrm{C}$ of $27 \pm 2 \mathrm{kbar}$ based on the isopleths from the GJTQ experiments in Fig. 10B.

The use of the chemical composition of the synthetic amphiboles as a quantitative indicator for pressure and temperature is somewhat uncertain because of (1) the difference and complexity of the buffering assemblage in the natural samples compared to our experiments, (2) the scatter in the data due to the formation of small amounts of melts and possible microdomains and contamination problems, and (3) the disappearance of talc in some of the experiments at 750 and $800{ }^{\circ} \mathrm{C}$, which leaves these experiments unbuffered in terms of $\mathrm{Mg}$.

Despite these uncertainties, the experimental data clearly demonstrate that the synthetic sodic amphiboles are displaced from stoichiometric glaucophane, similar to studies by Carman and Gilbert (1983), Pawley (1992), and Welch and Graham (1992). Our results quantify this displacement in the NMASH system, and require a decrease in the activity of the glaucophane component in sodic amphiboles grown from the bulk composition $\square \mathrm{Na}_{2} \mathrm{Mg}_{3} \mathrm{Al}_{2} \mathrm{Si}_{8} \mathrm{O}_{22}(\mathrm{OH})_{2}$. This has implications for the thermodynamic data of glaucophane, which are derived from the locus of reaction (1). Any future experimental work on reaction (1) should include detailed microprobe analysis of the run products to correct for solid solutions in the experiments.

Acknowledgments This work was supported by NSF grants EAR 95-26596 and EAR 92-05649 to EJE and EAR 94-05999 to CEM, a fellowship from the Austrian Bundesministerium für Wissenschaft und Forschung, and grants from the International Institute of the University of Michigan, Turner Fund of the Department of Geological Sciences at the University of Michigan, and the Geological Society of America to PT. Heather Lin, Tom LaTourette, Robert Newton, and Kurt Knesel are thanked for their help in the UCLA piston-cylinder laboratory, Wayne Dollase for his help with the X-ray diffractometer, and Frank Kyte and Patricia Weston for their help with the electron microprobe. The authors greatly appreciate the editorial handling by Timothy Grove, and the thorough reviews by David Jenkins and Alison Pawley, all of which helped to clarify the manuscript considerably.

\section{References}

Afifi A, Essene EJ (1988) MINFILE, a microcomputer program for storage and manipulation of chemical data on minerals. Am Mineral 73: 446-448

Boettcher AL, Wyllie PJ (1969) Phase relationships in the system $\mathrm{NaAlSiO}_{4}-\mathrm{SiO}_{2}-\mathrm{H}_{2} \mathrm{O}$ to 35 kilobars pressure. Am J Sci 267: 875-909

Bohlen SR (1984) Equilibria for precise pressure calibration and a frictionless furnace assembly for the piston-cylinder apparatus. Neues Jahrb Mineral Monatsh 9: 404-412

Bohlen SR, Boettcher AL (1982) The quartz-coesite transformation: a precise determination and the effects of other components. J Geophys Res 87: 7073-7078

Carman JH (1974) Synthetic sodium phlogopite and its two hydrates: stabilities, properties and mineralogic implications. Am Mineral 59: 261-273

Carman JH, Gilbert MC (1983) Experimental studies on glaucophane stability. Am J Sci 283A: 414-437

Carswell DA (1990) Eclogites and the eclogite facies: definitions and classifications. In: Carswell DA (ed) Eclogite facies rocks. Blackie, New York, pp 1-13

Chopin C (1986) Phase relationships of ellenbergerite, a new high pressure $\mathrm{Mg}-\mathrm{Al}-\mathrm{Ti}$ silicate in pyrope-coesite quartzite from the Western Alps. Geol Soc Am Mem 164: 31-42

Ernst WG (1961) Stability relations of glaucophane. Am J Sci 259: $735-765$

Ernst WG (1963) Polymorphism in alkali amphiboles. Am Mineral 48: 241-260

Ernst WG, Liu J (1998) Experimental phase-equilibrium study of Al- and Ti-contents of calcic amphibole in MORB - a semiquantitative thermobarometer. Am Mineral 83: 952-969

Essene EJ, Hensen BJ, Green DH (1970) Experimental study of amphibolite and eclogite stability. Phys Earth Planet Inter 3: 378-384

Gillet P, Reynard B, Tequi C (1989) Thermodynamic properties of glaucophane: new data from calorimetric and spectroscopic measurements. Phys Chem Mineral 16: 128-138

Hirajima T, Compagnoni R (1993) Petrology of a jadeite/coesitealmandine-phengite fels with retrograde ferro-nyböite from the Dora Maira Massif, Western Alps. Eur J Mineral 5: 943-955

Hirajima T, Zhang R, Li J, Cong B (1992) Petrology of the nyböitebearing eclogite in the Donghai area, Jiangsu Province, eastern China. Mineral Mag 56: 37-46

Holland TJB (1980) The reaction albite $=$ jadeite + quartz determined experimentally in the range $600-1200{ }^{\circ} \mathrm{C}$. Am Mineral 65: 129-134

Holland TJB, Powell R (1998) An internally consistent thermodynamic data set for phases of petrological interest. J Metamorph Geol 16: 309-343

Jenkins DM (1994) Experimental reversals of the aluminum content in tremolitic amphiboles in the system $\mathrm{H}_{2} \mathrm{O}-\mathrm{CaO}-\mathrm{MgO}-$ $\mathrm{Al}_{2} \mathrm{O}_{3}-\mathrm{SiO}_{2}$. Am J Sci 294: 593-620

Johannes W, Chipman DW, Hays JF, Bell PM, Mao HK, Newton RC, Boettcher AL, Seifert F (1971) An interlaboratory comparison of piston-cylinder pressure calibration using the albitebreakdown reaction. Contrib Mineral Petrol 32: 24-38

Johnson MC, Rutherford MJ (1989) Experimental calibration of the aluminium-in-hornblende geobarometer with application to Long Valley Caldera (California) volcanic rocks. Geology 17: 837-841

Koons PO (1982) An experimental investigation of the behavior of amphibole in the system $\mathrm{Na}_{2} \mathrm{O}-\mathrm{MgO}-\mathrm{Al}_{2} \mathrm{O}_{3}-\mathrm{SiO}_{2}-\mathrm{H}_{2} \mathrm{O}$ at high pressures. Contrib Mineral Petrol 79: 258-267

Kretz R (1983) Symbols for rock-forming minerals. Am Mineral 68: $277-279$

Laird J (1982) Amphiboles in metamorphosed basaltic rocks: greenschist facies to amphibolite facies. In: Veblen DR, Ribbe 
PH (eds) Amphiboles: petrology and experimental phase relations. Rev Mineral 9A: 113-117

Laird J, Albee AL (1981) High-pressure metamorphism in mafic schist from northern Vermont. Am J Sci 281: 97-126

Leake BE, Wooley AR, Arps CES, et al (1997) Nomenclature of amphiboles: report of the Subcommittee on Amphiboles of the International Mineralogical Association, Commission on New Minerals and Mineral Names. Can Mineral 35: 219-246

Liu J, Bohlen SR (1995) Mixing properties and stability of jadeiteacmite pyroxene in the presence of albite and quartz. Contrib Mineral Petrol 119: 433-440

Liu J, Bohlen SR, Ernst WG (1996) Stability of hydrous phases in subducting oceanic crust. Earth Planet Sci Lett 143: 161-171

Manning CE, Boettcher SL (1994) Rapid-quench hydrothermal experiments at mantle pressures and temperatures. Am Mineral 79: $1153-1158$

Maresch WM (1973) New data on the synthesis and stability relations of glaucophane. Earth Planet Sci Lett 20: 385-390

Maresch WM (1977) Experimental studies on glaucophane: an analysis of present knowledge. Tectonophysics 43: 109-125

Maresch WM, Czank M (1983) Problems of compositional and structural uncertainty in synthetic hydroxyl-amphiboles; with an annotated atlas of the Realbau. Period Mineral 52: 463-542

Maruyama S, Cho M, Liou JG (1986) Experimental investigations of blueschist-greenschist transition equilibria: pressure dependence of $\mathrm{Al}_{2} \mathrm{O}_{3}$ contents in sodic amphiboles - a new geobarometer. Geol Soc Am Mem 164: 1-16

Maruyama S, Liou JG, Terabayashi M (1996) Blueschists and eclogites of the world and their exhumation. Int Geol Rev 38: 485-563

Mirwald PW, Getting IC, Kennedy GC (1975) Low-friction cell for piston-cylinder high temperature apparatus. J Geophys Res 80 : $1519-1525$

Okay AI (1993) Petrology of a diamond and coesite-bearing metamorphic terrain Dabie Shan, China. Eur J Mineral 5: 659-675

Pawley AR (1992) Experimental study of the compositions and stability of synthetic nyböite and nyböite-glaucophane amphiboles. Eur J Mineral 4: 171-192
Pawley AR, Holloway JR (1993) Water sources for subduction zone volcanism: new experimental constraints. Science 260: 664-667

Pawley AR, Graham CM, Navrotsky A (1993) Tremolite-richterite amphiboles: synthesis, compositional and structural characterization and thermochemistry. Am Mineral 78: 23-35

Robie RA, Hemingway BS, Gillet P, Reynard B (1991) On the entropy of glaucophane, $\mathrm{Na}_{2} \mathrm{Mg}_{3} \mathrm{Al}_{2} \mathrm{Si}_{8} \mathrm{O}_{22}(\mathrm{OH})_{2}$. Contrib Mineral Petrol 107: 484-486

Schertl HP, Schreyer W, Chopin C (1991) The pyrope-coesite rocks and their country rocks at Parigi, Dora Maira Massif, Western Alps: detailed petrography, mineral chemistry and PTpath. Contrib Mineral Petrol 108: 1-21

Sharma A (1996) Experimentally derived thermochemical data for pargasite and reinvestigation of its stability with quartz in the system $\mathrm{Na}_{2} \mathrm{O}-\mathrm{CaO}-\mathrm{MgO}-\mathrm{Al}_{2} \mathrm{O}_{3}-\mathrm{SiO}_{2}-\mathrm{H}_{2} \mathrm{O}$. Contrib Mineral Petrol 125: 263-275

Tropper P (1998) Experimental and field-related investigations on the metamorphic history of eclogites in the Sesia-Lanzo Zone, Western Alps (Italy). PhD Thesis, Univ Michigan, Ann Arbor

Ungaretti L, Smith DC, Rossi G (1981) Crystal-chemistry by X-ray structure refinement and electron microprobe analysis of a series of sodic-calcic to alkali-amphiboles from the Nybö eclogite pod, Norway. Bull Mineral 104: 400-412

Venturini G (1995) Geology, geochemistry and geochronology of the inner central Sesia Zone (Western Alps, Italy). Mém Geol, Lausanne, 25

Welch MD, Graham CM (1992) An experimental study of glaucophanic amphiboles in the system $\mathrm{Na}_{2} \mathrm{O}-\mathrm{MgO}-\mathrm{Al}_{2} \mathrm{O}_{3}-$ $\mathrm{SiO}_{2}-\mathrm{SiF}_{4}$ (NMASF): some implications for glaucophane stability in natural and synthetic systems at high temperatures and pressures. Contrib Mineral Petrol 111: 248-259

Zhang RY, Liou JG (1994) Coesite-bearing eclogite in Henan Province, central China: detailed petrography, glaucophane stability and P-T path. Eur J Mineral 6: 217-233 